\title{
Pathogenesis, Diagnosis and Possible Therapeutic Options for COVID-19
}

\author{
Md. Asad Ullah ${ }^{1 *}$, Yusha Araf ${ }^{2}$, Bishajit Sarkar ${ }^{1}$, Abu Tayab Moin ${ }^{3}$, Riyan Al Islam Reshad ${ }^{2}$, \\ MD. Hasanur Rahman ${ }^{4}$
}

${ }^{1}$ Department of Biotechnology and Genetic Engineering, Faculty of Biological Sciences, Jahangirnagar University, Dhaka, Bangladesh

${ }^{2}$ Department of Genetic Engineering and Biotechnology, School of Life Sciences, Shahjalal University of Science and Technology, Sylhet, Bangladesh

${ }^{3}$ Department of Genetic Engineering and Biotechnology, School of Life Sciences, University of Chittagong, Chottogram, Bangladesh

${ }^{4}$ Department of Biotechnology and Genetic Engineering, Bangabandhu Sheikh Mujibur Rahman Science and Technology University, Faculty of Life Sciences, Gopalganj, Bangladesh

\section{Correspondence:}

Md. Asad Ullah

Address: Department of Biotechnology and Genetic Engineering, Faculty of Biological Sciences, Jahangirnagar University, Dhaka, Bangladesh

Email: ullah1194@gmail.com

Received: 14.06.2020,

Accepted: 27.07.2020

https://doi.org/10.29333/jcei/8564

\begin{abstract}
The recent pandemic caused by severe acute respiratory syndrome coronavirus 2 (SARS-CoV2) has spread so rapidly and severely affected the people of almost every country in the world. The highly contagious nature of this virus makes it difficult to take control of the present pandemic situation. With no specific treatment available, the coronavirus disease 2019 (COVID-19) presents a threat to people of all ages including the elderly people and people with other medical complications as a vulnerable group to this disease. Better understanding of viral pathogenesis, appropriate preventive measures, early diagnosis and supportive treatments of the infected patients are now the general solutions to fight against this viral transmission. But, as an emerging disease, most about it remains still poorly understood. This article holds an overview on the origin and structure, pathogenesis, diagnosis and possible therapeutic options for the causative agent, SARS-CoV-2 and disease, COVID-19. However, few therapeutic options, laboratory experiments and other strategies proposed here need to be further clinically tested.
\end{abstract}

Keywords: COVID-19, diagnosis, pathogenesis, treatment, SARS-CoV-2

\section{INTRODUCTION}

The severe acute respiratory syndrome corona virus 2 (SARS-CoV-2) known to cause coronavirus disease 2019 (COVID19 ), is rapidly spreading from its origin in Wuhan City of Hubei Province of China to the rest of the world [1]. A large number of people have been affected with the 3 epidemics caused by coronavirus family over the last few decades in the world. In the previous epidemics, origins of those diseases were Middle East, Saudi Arabia (Middle East Respiratory Syndrome coronavirus (MERS$\mathrm{CoV})$ ) and China (SARS-CoV) where animal to human transmission was first reported, and the transmissions of pathogens were reported in other countries subsequently [2,3]. Epidemiological evidence in China suggested that recent SARS-CoV-2 outbreak began from a seafood and live animal shopping center in Wuhan, Hubei Province in the mid of December 2019 [4]. COVID-19 case number has risen so rapidly in the world compared to SARS$\mathrm{CoV}$ and MERS-CoV outbreaks, and it is supposed take longer to halve the disease cases; indicating that control measures would have to be in place for a significant time period [5]. On 12 March, 2020, WHO declared COVID-19 as pandemic pointing the spread of the virus in more than hundred countries and few territories [6]. Coronaviruses are commonly known as highly diverse, enveloped, positive-sense, single-stranded RNA viruses which cause several diseases of respiratory, enteric, hepatic and neurological systems with varying severity of the cases among humans and animals [7,8]. Serology and genome phylogeny classify coronaviruses into four genera termed Alpha, Beta, Gamma and Delta coronavirus. Seven human coronavirus strains have been identified so far, containing two alpha $\mathrm{CoVs}$ ( $\mathrm{HCoV}$ 229E and HCoV-NL63) and five beta CoVs (HCoV-OC43, HCoV-HKU1, SARS-CoV, MERS-CoV and SARS-CoV [9] Three coronaviruses namely, SARS-CoV, MERS$\mathrm{CoV}$ and SARS-CoV-2 have emerged and caused severe human diseases over the past 
two decades $[10,11]$. There are few overlapping and discrete aspects of the pathology and pathogenesis of these coronaviruses which cause severe lung diseases in humans upon infection owing to eventual death in critical very cases [12]. As of April 13, 2020, SARS-CoV-2 was reported to spread in 210 countries and territories around the world including 2 international conveyances and taken more than one hundred thousand lives with almost 1.8 million more infected cases [13]. Understanding the pathogenesis of SARS-CoV-2 infection, early diagnosis and supportive treatments are crucial to combat the outbreak of this highly contagious virus. This article includes an overview on molecular pathogenesis, diagnosis and possible therapeutic options for COVID-19 which should hold a scientific understanding necessary to prevent the viral transmission.

\section{ORIGIN AND CHARACTERISTICS OF SARS-}

\section{CoV-2}

The novel coronavirus, commonly known to cause COVID-19, is delineated as novel pneumonia that occurs due to infection by a strain that was initially detected in Wuhan, Hubei province, China [14]. Name of the strain and disease was first introduced by The International Committee on Taxonomy of Viruses (ICTV). That particular strain was called SARS-CoV-2 and the disease was designated as COVID-19 [15-19]. This novel virus is one type of $\beta$ coronavirus that is enveloped, non-segmented and positivesense RNA virus (subgenus sarbecovirus, Orthocoronavirinae subfamily) [20].

According to the current research, the first case of corona virus infection in human was discovered in 17 November, 2019 [21]. The authentic source of this patgogen's transmission to humans still seems obscure [22-24]. It has been suggested that the strain might have been originated from the Huanan Seafood Market where bats, snakes, raccoon dogs, palm civets, and other animals are sold. From the wet market it rapidly spread up to 210 countries and territories around the world by April 12, 2020 [25]. The workers at the market were the first to be detected with this disease $[26,27]$. There was also a prediction which claims that the visitors, not the workers, were the ones who introduced the disease to the market. Later, the disease was transmitted over the mass population $[22,28]$. Notwithstanding, there is no confirmed information which manifests that SARS-CoV2 was originated from that wet market.

Certainly, bats are considered as the natural reservoir of broad and diversified range of CoVs. However, to find out the origin of SARS-CoV-2 the natural reservoir of SARSCoV, which caused the previous 2002-2004 SARS outbreak, was analyzed. The analysis resulted in the discovery of many SARS-like bat coronaviruses which were predominantly originated in the Rhinolophus genus of horseshoe bats. SARS-CoV-2 and two viral RNA sequences found in samples taken from Rhinolophus sinicus demonstrated approximately $80 \%$ similarity to SARS-CoV-2 [29-31]. Moreover, another
RNA sequence of Rhinolophus affinis (RaTG13), found in Yunnan province, has a $96.2 \%$ analogy with SARS-CoV-2 $[32,33]$. Consequently, bats are contemplated as the most probable natural reservoir of SARS-CoV-2 [34,35]. In spite of all these significant difference lies between the bat coronavirus and SARS-CoV-2. Similarly contrasting features between SARS-CoV and SARS-CoV-2 have also been noticed according to genomic analysis. Though SARS-CoV2 shares $79.5 \%$ genomic identity to SARS-CoV, five of the total six amino acids of receptor-binding domain(RBD) of $S$ protein that are crucial for binding to human receptor ACE2 were found to differ between them. But still according to the structural studies and biochemical experiments, RBD of SARS-Cov-2 appears to have high affinity to bind with human ACE2. However, it has now been clarified that, this virus has not been originated by any purposeful laboratory manipulation [15-20,36,37]. Also, there exists an unrecognized intermediate host by which viral transmission took place from bat to human via recombination [38].

Some primary reports state that two species of snakes also could be probable reservoir of disease COVID-19. However, there exists no strong evidence of coronavirus reservoirs other than mammals and birds. Again, genomic analysis predicts that there is another source which is significantly identical with the viral RNA sequence. Pangolin-CoV and SARS-CoV-2 have been proved to have $99 \%$ similarity in the receptor -binding domain of the S protein [21][24][39]. In spite of all these, the similarity of coronavirus from pangolin to newly emerged SARS-CoV-2 is not as much as the analogy of RaTG13 to SARS-CoV-2 [40]. That is because pangolinCoV shares only $92 \%$ of their complete genomes with SARS$\mathrm{CoV}-2$. Hence, it is inadequate to prove the effectiveness of pangolin as an intermediate host. A metagenomic study of 2019 depicts that, SARS-CoV was the most widely distributed coronavirus among a sample of Sunda pangolins [41]. Thus, they might act as an intermediate host and went through recombination and then infected humans. According to another study, recombination in the host intermediate of novel corona virus actively facilitated the virus to attain accelerated rate of transmission compared to SARS-CoV. Moreover, analysis of homolgous recombination illustrates that receptor binding spike glycoprotein of novel coronavirus evolved from a SARS-CoV (CoVZXC21 or CoVZC45) and an unidentified Beta-CoV. Therefore, we are anticipating to detect the authentic intermediate host via which the virus was directly transmitted to humans.

SARS CoV-2 genome was elucidated to contain 14 open reading frames (ORFs) encoding 27 proteins. At the $5^{\prime}$ terminus of the genome, two genes are located namely: orflab (encodes pp1ab protein) and orfla (encodes for ppla protein). Altogether, they constitute 16 non-structural proteins (nsps) (nsp1-nsp10 and nsp12-nsp16) (Figure 1). Genes at the 3' terminus encode for structural proteins 


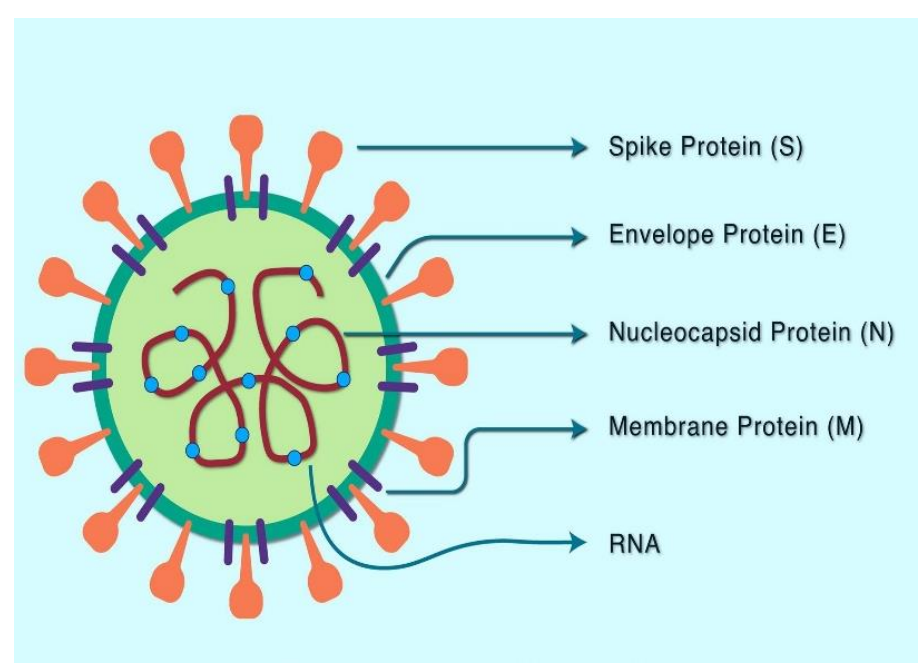

(A)
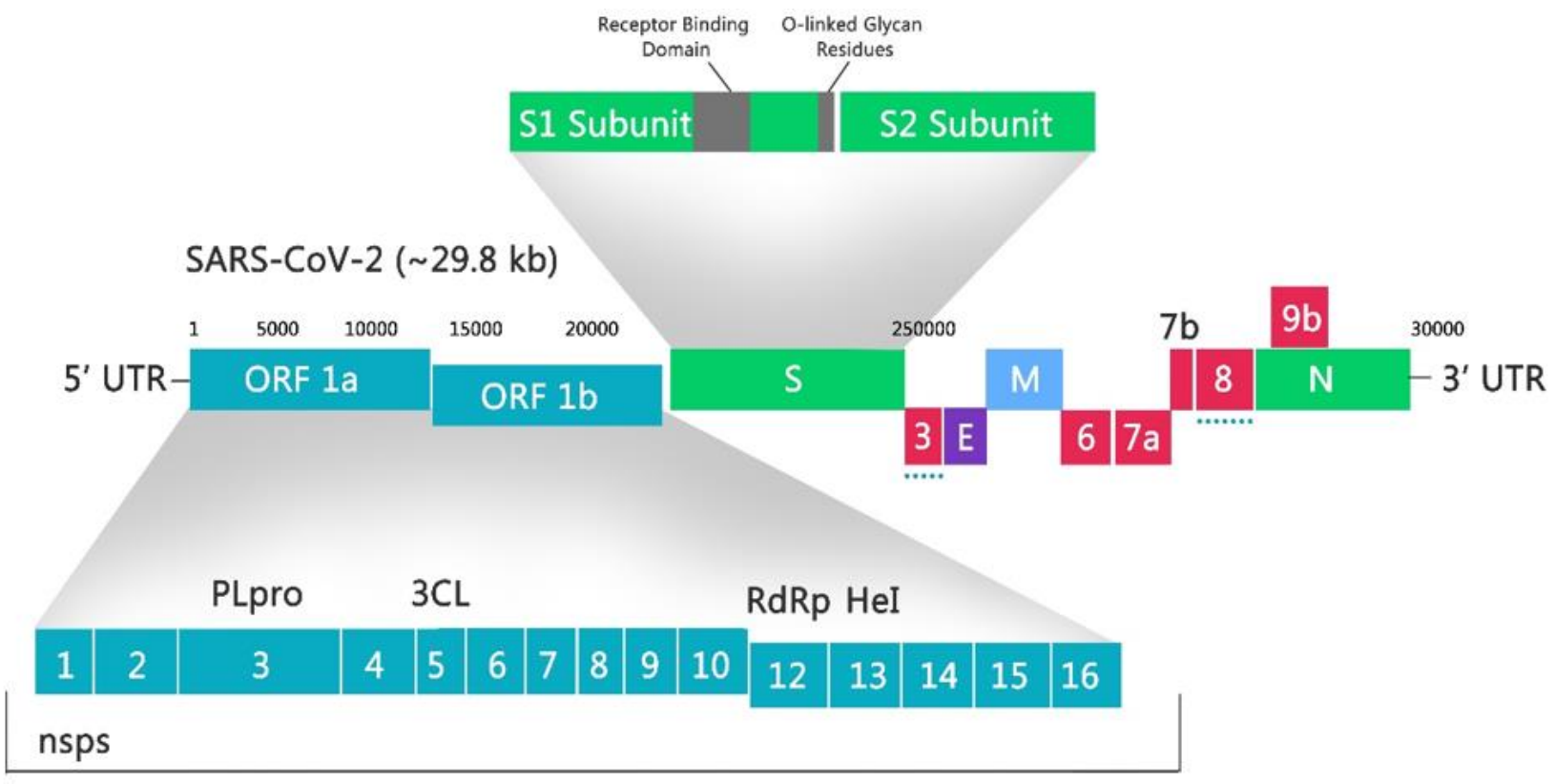

(B)

Figure 1. (A) Typical structure of SARS-CoV-2; (B) organization of SARS-CoV-2 viral genome. 3CL: 3-chymotripsin-like protease; PLpro: Papain-like protease; RdRp: RNA-dependent RNA polymerase. Hel: Helicase.

including Hemagglutinin Esterase (HE) (found in betaCoVs), Spike (S), Small Membrane (E), Membrane (M), Nucleocapsid (N) and Internal (I) protein. Nucleocapsid protein complexes and viral RNA and together develop a helical capsid shape. Formation of peplomers integrated in the envelope and finally giving it a corona or crown shape peplomers which is done by Spike protein trimers [38,42]. In some cases, trasmembrane protein HE forms small spikes. " $M$ " and "E" proteins of the viruses work for final virus assembly. Structural proteins also include eight accessory proteins: $3 \mathrm{a}, 3 \mathrm{~b}, \mathrm{p} 6,7 \mathrm{a}, 7 \mathrm{~b}, 8 \mathrm{~b}, 9 \mathrm{~b}$, and orf14. If compared at amino acid level, the sequence of SARS-CoV-2 is almost same as that of SARS-CoV. Still, some significant dissimilarities between them were found. For instance: The 8 a protein is common for SARS-CoV, but in SARS-CoV-2, it is absent. The $8 \mathrm{~b}$ protein of SARS-CoV has 84 amino acids, whereas, that of SARS-CoV-2 is much longer (121 amino acids). The $3 \mathrm{~b}$ protein of SARS-CoV comprises of 154 amino acid, but in case of SARS-CoV-2, it is very much shorter (only 22 amino acids). Through further studies, it is possible to determine how the differences influence the activity and degree of pathogenicity of SARS-CoV-2 [42,43].

\section{PATHOGENESIS OF SARS-CoV-2 INFECTION}

Mode of SARS-CoV-2 Transmission and Viral Entry

\section{Inside the Cell}

Wild animals including bats are the possible hosts and reservoirs of the SARS-CoV-2. The human-to-human transmission of SARS-CoV-2 is achieved mainly via respiratory droplets of an infected individual. However, the virus can also be transmitted through the aerial droplets and contact even with an asymptomatic COVID-19 patient [44- 


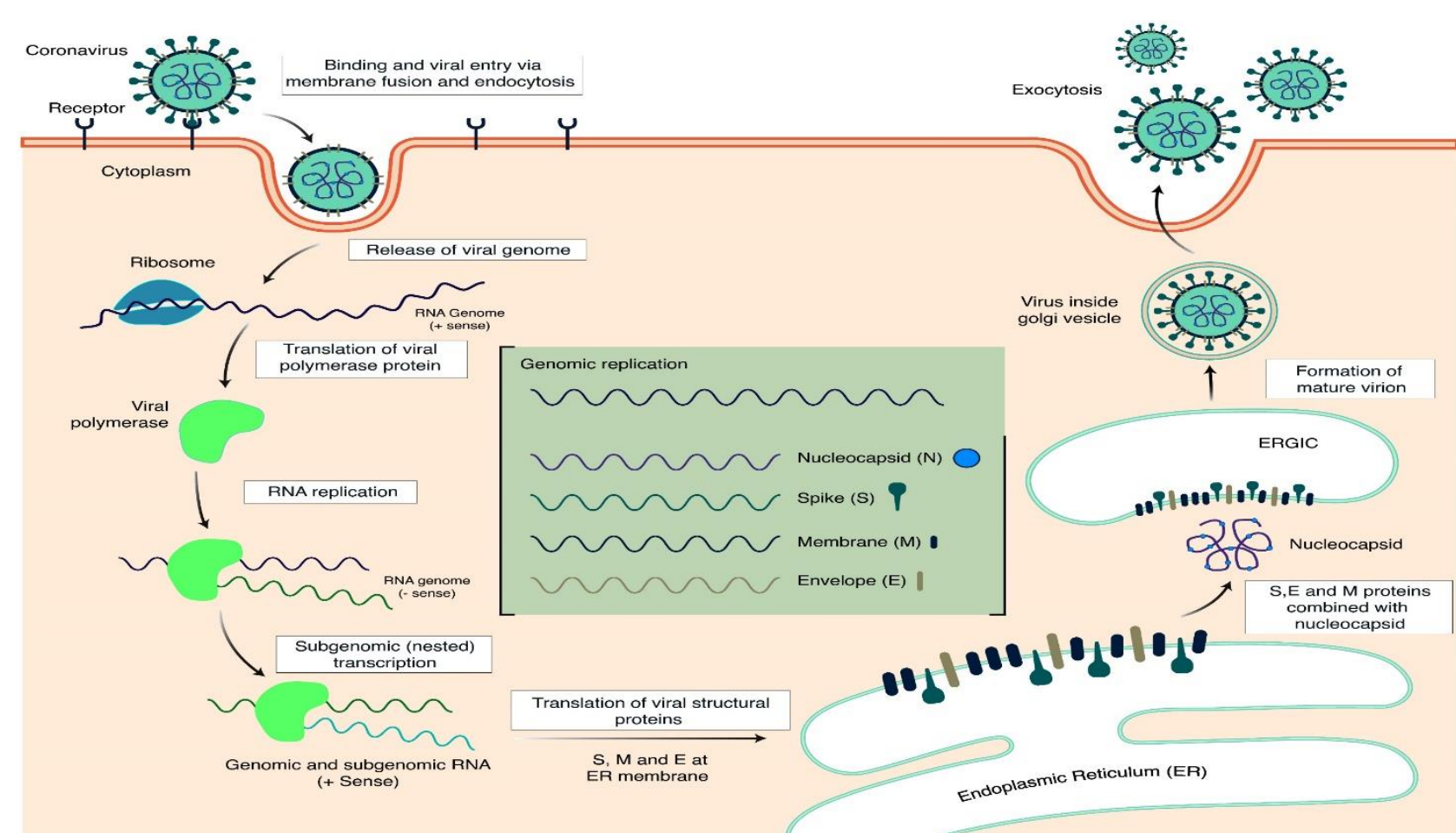

Figure 2. Reproductive cycle of SARS-CoV-2 in mediating the viral pathogenesis. Virus enters the cells via exocytosis after binding to ACE2 receptor and then replicate their genome in multiple copies and transcribe viral proteins. After assembly of virions, they lyse the host cells and get outside of the infected cells via endocytosis and the newly formed viruses infect more healthy cells. ER: Endoplasmic reticulum; ERGIC: Endoplasmic reticulum-Golgi intermediate complex.

46]. The presence of this virus has also been reported in the feces of the COVID-19 patient but whether the virus from feces can cause the disease or not is still poorly understood [47].

After entering the human body, SARS-CoV-2 first enters the cells of the host before replication. The first step in viral entry to human cell is the binding of a viral trimeric protein called spike protein with the human receptor angiotensin converting enzyme 2 (ACE2) (Figure 2). These spike proteins protruding from the membrane of the virus are responsible for the characteristic shape of the virus. TheACE2 receptor is responsible for the entry of both SARSCoV-2 and SARS-CoV inside the cells of human body [48]. The viral spike proteins mediate the van der Waals interaction with ACE2 receptors during the viral entry which is a critical step in the manifestation of viral infection. Another type of proteins called transmembrane protease serine 2 (TMPRSS2) is required for initial priming of the spike protein with the ACE2 receptor [49]. After the receptor binding and processing by TMPRSS2 the virus enters the host cell via endocytosis. The SARS-CoV-2 and SARS-CoV spike proteins have almost $77 \%$ sequence identity and importantly a high degree of homology [50]. Recent study suggests that, the SARS-CoV-2 spike protein can bind with ACE2 receptors more effectively than that of SARS-CoV and hence the SARS-CoV-2 might be more effective in invading the human cells than SARS-CoV [18,51]. After entering the cell, the virus triggers replication to produce multiple copies of viral materials and after assembly it lyses the infected cells to get out in multiple copies and continue the infection of more healthy cells.

\section{Replication of Coronavirus inside Human Body}

The genome of coronavirus is a single-stranded positive sense RNA of approximately 30 kilobase size with typical 5'cap and 3'-poly A tail structures. The whole genomic RNA serves as a template for the translation of replicasetranscriptase protein encoded in two open reading frames (ORFs) i.e., ORF1a and ORF1b. The replicase-transcriptase proteins are initially encoded as two large polyproteins i.e., pp1a and pp1b (Figure 1) [52]. These polyproteins are cleaved during or after the synthesis by virus-encoded proteinases i.e., papain like and chymotrypsin like proteases into 15 nonstructural viral proteins i.e., nsp1 to nsp10 encoded in ORF1a and nsp12 to nsp16 encoded in ORF1ab. These non-structural proteins together with other viral proteins and possibly with cellular proteins aggregate with membrane-bound replication-transcription complex (RTC) $[42,53]$. The RTC binds to the regulatory sequences that reside inside the coronavirus genome and may continuously copy the whole genome into a genome-length template or discontinuously into several subgenome length RNA template. These various length subgenomic RNAs then serve as the template for the production of subgenomic mRNAs [54]. The termination of transcription of subgenome mRNAs and the further acquisition of a leader RNA occurs at the transcription regulatory sequences present in the ORFs 
Pathogenesis, Diagnosis and Therapeutics for COVID-19

Table 1. Elevated and decreased cytokines and chemokines in different disease caused by SARS-related coronaviruses

\begin{tabular}{|c|c|c|c|}
\hline \multirow[t]{2}{*}{ Disease } & \multicolumn{2}{|l|}{ Cytokines and Chemokines } & \multirow[t]{2}{*}{ References } \\
\hline & Elevated & Decreased & \\
\hline SARS & TNF, IL-6, CCL3, CCL5, CCL2, CXCL10, IFN- - , IL-1, IL-6, IL-12, TGF $\beta$, CCL2, CXCL10, CXCL9 and IL-8 & IL-10, IFN- $\alpha$, IFN- $\beta$ & {$[61-66]$} \\
\hline MERS & CCL-2, CCL-3, CCL-5, IL-2, IL-8, CXCL-10, IL-6 & - & [67-70] \\
\hline COVID-19 & IL-6, IL-10, TNF $\alpha$, CXCL10 IL-2, II-7, GSCF, MCP-1 and MIP-1a & IFN- $\gamma$ & {$[71-74]$} \\
\hline
\end{tabular}

[55]. These mRNAs are then translated into different proteins required for virus assembly i.e., spike proteins, membrane glycoproteins, nucleocapsid proteins. After assembly of new viruses in multiple copies, they lyse the infected cells and get outside and continue to infect new healthy cells. So overall, the coronavirus mediates its infection in few typical steps: (i) Transmission inside human body and binding of virus spike protein with ACE2 receptors of cell membrane, (ii) Membrane fusion of the virus through endocytosis and release of the viral genome inside cell, (iii) Synthesis of RTC and replication of viral RNA, (iv) Transcription of subgenomic mRNAs, (v) Translation of the viral proteins, (vi) Assembly of new virions, (vii) Release of virion from infected cells via exocytosis and infect new healthy cells (Figure 2) [56]. Thus, the virus continues to infect new healthy cells continually which leads to progressive lung damage that characterizes the pneumonia owing to multiple organ failure and death in very critical cases. Release of virus outside of the cells in the lungs result in the aggregation of immune cells which produce abundant immune mediators and lead to acute inflammation.

Human Immune Responses Against the SARS-CoV-2 and Other SARS-related Viral Infection

As an emerging disease, most about the immune response of COVID-19 inside human body remains poorly understood. Viral RNAs are recognized by the components of innate immune systems that include three major classes of cell surface receptors i.e., Toll-like receptors (TLRs), RIG-Ilike receptors (RLRs) and NOD-like receptors (NLRs), which initiate the expression of interferon (IFN) and activation of anti-viral effectors of both innate and adaptive immunity i.e., Natural Killer cells, T CD8+ cells and macrophages [57-60].

Elevated amounts of cytokines (cytokine storm) was observed in SARS patients. SARS-CoV infection of dendritic cells (DCs) induces low-level expression of antiviral cytokines Interferon- $\alpha$ and $\beta$ (IFN- $\alpha \beta$ ), moderate upregulation of pro-inflammatory cytokines i.e., tumor necrosis factor (TNF) and interleukin-6 (IL-6), and a significant up-regulation of inflammatory chemokines C-C Motif Chemokine Ligand 3 (CCL3), CCL5, CCL2, and C-XC motif chemokine 10(CXCL10) [61][62]. Moreover, Proinflammatory cytokines Interferon- $\gamma($ IFN- $\gamma)$, IL- 1, IL-6, IL12, and Transforming growth factor $\beta$ (TGF $\beta$ ) and chemokines i.e., CCL2, CXCL10, CXCL9, and IL-8 were also found in elevated amounts in severe SARS disease patient compared to mild patient. On the contrary, SARS patients with very severe disease were examined to have very low levels of the anti-inflammatory cytokine, IL-10 (Table 1) [63-66].

In vitro and in vivo experiments on MERS infection suggests the release of increased amount cytokines and chemokines i.e., CCL-2, CCL-3, CCL-5, IL-2, and IL- 8 by different immune cells $[67,68]$. Elevated levels of serum proinflammatory cytokines i.e., IL- 6 and IFN- $\alpha$ and chemokines i.e., IL-8, CXCL-10, and CCL5 were also observed in individuals with severe MERS compared to patients with mild disease $[69,70]$.

A recent study has found increased expressions of cytokines i.e., IL-6, IL-10, and TNFa, lymphopenia in both types of T cells but decreased expression of IFN- $\gamma$ in patients with severe COVID-19 [71]. Another study has found significant correlation between elevated level of CXCL10, monocyte chemotactic protein-3 (MCP-3), IL-1ra and severity and progression of COVID-19 [72]. Increased plasma levels of IL-2, IL-7, Granulocyte-colony stimulating factor (GCSF), MCP-1 and Macrophage Inflammatory Protein-1a (MIP-1a) has also been found in severe cases of COVID-19 $[73,74]$.

\section{DIAGNOSIS OF COVID-19 PATIENT}

Initially the COVID-19 patients are identified on the basis of presence of clinical symptoms associated with primary stage of disease progression. But confirmatory test of the COVID-19 patient can be achieved by variety of methods i.e., nucleic acid-based identification, computed tomography scan (CT scan), immune-reaction based techniques in the laboratory (Table 2).

\section{Real-time Quantitative Polymerase Chain Reaction (RT-qPCR)}

RT-qPCR provides an efficient method for the detection of the presence of the virus in COVID-19 patients. The technique involves the viral RNA extraction from the respiratory samples, oropharyngeal swab, saliva of the COVID-19 patients. Then the specific sequence in viral genome is amplified in multiple copiesin conventional manner in the presence of reaction buffer, Taq polymerase, master mix in a thermal cycler under appropriate conditions [75]. Different gene sequences can be targeted as the intended amplicons i.e., RdRp gene: RNA-dependent RNA polymerase gene, $\mathrm{E}$ gene: envelope protein gene, $\mathrm{M}$ gene: membrane protein gene, $\mathrm{N}$ gene: nucleocapsid protein gene, $S$ gene: spike protein gene or other open reading frame (ORF) gene. The amplification of any of these gene can be 
Pathogenesis, Diagnosis and Therapeutics for COVID-19

Table 2. Different diagnosis methods for the detection of SARS-CoV-2. NA: Not Allowed

\begin{tabular}{lllll}
\hline $\begin{array}{l}\text { Diagnosis } \\
\text { Methods }\end{array}$ & Mechanism of Detection & Specimen & Advantages & Disadvantages \\
\hline RT-qPCR & $\begin{array}{l}\text { Polymerase chain reaction / } \\
\text { hybridization reaction, } \\
\text { electrophoretic separation }\end{array}$ & $\begin{array}{l}\text { Respiratory samples, } \\
\text { oropharyngeal swab, } \\
\text { saliva }\end{array}$ & $\begin{array}{l}\text { Specific and sensitive } \\
\text { [75-78] }\end{array}$ & $\begin{array}{l}\text { Laborious, time consuming, } \\
\text { hazardous, labor extensive, costly }\end{array}$ \\
\hline CT Scan & $\begin{array}{l}\text { X ray beam imaging of chest of } \\
\text { patient, inspection of lung } \\
\text { abnormalities }\end{array}$ & NA & $\begin{array}{l}\text { Effective, specific, Non- } \\
\text { hazardous, non-laborious }\end{array}$ & $\begin{array}{l}\text { Incapable of discriminating } \\
\text { different lung abnormalities, } \\
\text { costly }\end{array}$ \\
\hline $\begin{array}{l}\text { Testing Kits/ } \\
\text { ELISA }\end{array}$ & $\begin{array}{l}\text { Antigen-antibody reaction, } \\
\text { colorimetric interpretation }\end{array}$ & Blood, serum, plasma & $\begin{array}{l}\text { Rapid, sensitive, cost- } \\
\text { effective }\end{array}$ & $\begin{array}{l}\text { Might be incapable of detection } \\
\text { during initial stage of infection }\end{array}$ \\
\hline [86-87]
\end{tabular}

achieved by providing appropriate forward and reverse primers. A recent study has found $95 \%$ sensitivity of the PCR amplification of $\mathrm{E}$ and RdRp gene rom SARS coronavirus $[26,76]$. Another study suggested that, the presence of SARS CoV-2 virus can be detected from the stool of the infected patient using the nucleic-acid based detection techniques. Again, the same study found negative results with both nucleic acid-based tests and test kits from the urine and blood sample of the patient. This is might be due to the low concentration of the virus in those samples [77]. Another study found $91.7 \%$ positive rates (11/12 patients) in RTqPCR test using saliva sample from COVID-19 patients, suggesting that saliva could be a non-invasive sample from the infected patient [78]. However, although the RT-qPCR is an effective technique for the identification of SARS-CoV-2 virus from COVID-19 patients but it may come out with false positive results sometime and the technique itself is highly laborious and involves the management of biohazards.

\section{CT Scan Imaging}

Although the RT-qPCR is a specificSARS-CoV-2 detection technique but the chance of false positive results can't be ignored. Therefore, many clinicians offer the use of CT scan but use of the combination of both techniques is more helpful and thus CT scan can assist the mass identification in a heavily infected area. A recent study suggested that, CT scan is more sensitive in the detection of SARS-CoV-2 virus from COVID-19 patient than the PCRbased method [79]. Moreover, high resolution CT (HRCT) can be used effectively for the initial identification of the COVID-19 patient [80]. The technique utilizes narrow X-ray beam that circles around the body parts of the patient and provides a series of picture form different angles. A computer program then combines the multiple captures to provide a cross-sectional image. CT scan of COVID-19 patient showed abnormal image with the sign of bilateral multiple groundglass opacities or consolidation in recent studies $[81,82]$. Other findings also suggested the involvement of groundglass opacities is a common phenomenon in COVID-19 patient and the involvement of multilobes in the chest of CT image of COVID-19 patient was also observed in the same study. But other lung abnormalities i.e., lung cavitation, discrete pulmonary nodules, pleural effusions, and lymphadenopathy were absent [83][84]. Although, these findings suggest $\mathrm{CT}$ scan to be an effective identification method of SARS-CoV-2 but it also has few disadvantages i.e., incapability to discriminate between the abnormalities caused by pneumonia and other lung diseases and COVID19 [85].

\section{Immune Reaction-based Test Kits}

In addition to the above described techniques, antigenantibody $(\mathrm{Ag}-\mathrm{Ab})$ immune-reaction based kits provide more cost-effective and rapid diagnosis method. A recent study has proposed a detection method with proven $88.66 \%$ sensitivity and $90.63 \%$ specificity in laboratory experiment. The technique utilizes immune reaction of combined human antibodies i.e., immunoglobulin $\mathrm{M}(\operatorname{IgM})$ and $\operatorname{IgG}$ with SARS-CoV-2 coronavirus spike proteins from the blood sample of COVID-19 patient. This technique also showed consistent result for serum and plasma from venous blood and fingerstick blood sample [86]. Enzyme-linked immunosorbent assay (ELISA) based on the immune reaction can also be used for the detection of SARS-CoV-2. A study has suggested that the ELISA technique is capable of detecting the virus using recombinant nucleocapsid and spike viral proteins with positive rates of $80.4 \%$ and $82.2 \%$, respectively. However, the positive rate of the experiment was less $(60 \%)$ during the initial stage (0 to 10 days) of the infection which might be due to the low concentration of antibodies in blood sample [87]. Different techniques offer different sensitivity and different specificity of disease diagnosis. The use of identification method may vary depending on different conditions i.e., availability of raw materials, equipment, expertise, facilities, price etc. However, shortcomings of all the techniques force more effective diagnosis methods to be developed.

\section{MAJOR DRUG TARGETS AGAINST SARS-CoV-2}

Different proteins involved in different stage of vial life cycle of SARS-CoV-2 can serve as potential therapeutic targets for designing antiviral drugs (Table 3). The best possible therapeutic options for SARS-CoV-2 are 3chymotrypsin-like protease, papain-like protease, helicase, and RNA-dependent RNA polymerase, structural proteins i.e., spike glycoprotein. These proteins are essential for the maintenance of the virus life cycle and hence recognized as most attractive drug targets against SARS-CoV-2 [88]. 
Pathogenesis, Diagnosis and Therapeutics for COVID-19

Table 3. Summary of different possible drug targets against SARS-CoV-2

\begin{tabular}{|c|c|c|c|c|}
\hline Target Name & Target Category & Target Type & Function & References \\
\hline Spike protein & Membrane protein & Structural viral protein & $\begin{array}{l}\text { Attachment to host cell membrane and fusion inside } \\
\text { the cell. }\end{array}$ & {$[90]$} \\
\hline 3-chymotrypsin-like protease $\left(3 \mathrm{CL}^{\text {pro }}\right)$ & Enzyme & $\begin{array}{l}\text { Non-structural viral } \\
\text { protein }\end{array}$ & $\begin{array}{l}\text { Cleavage of polyprotein complex required for viral } \\
\text { replication and transcription. }\end{array}$ & [91] \\
\hline Papain-like protease (PL $\left.{ }^{\text {pro }}\right)$ & Enzyme & $\begin{array}{l}\text { Non-structural viral } \\
\text { protein }\end{array}$ & $\begin{array}{l}\text { Cleavage of polyprotein complex required for viral } \\
\text { replication and transcription. }\end{array}$ & [91] \\
\hline Helicase & Enzyme & $\begin{array}{l}\text { Non-structural viral } \\
\text { protein }\end{array}$ & $\begin{array}{l}\text { Nucleotide-triphosphatase, duplex RNA/DNA- } \\
\text { unwinding and RNA-capping }\end{array}$ & [92] \\
\hline $\begin{array}{l}\text { RNA-dependent RNA polymerase } \\
\text { (RdRp) }\end{array}$ & Enzyme & $\begin{array}{l}\text { Non-structural viral } \\
\text { protein }\end{array}$ & Replication and transcription of viral RNA and mRNA. & [93] \\
\hline $\begin{array}{l}\text { Angiotensin converting enzyme } 2 \\
\text { (Ace2) }\end{array}$ & Receptor & Host protein & $\begin{array}{l}\text { Recognition and interaction with viral spike protein } \\
\text { to assist viral entry. }\end{array}$ & {$[94,95]$} \\
\hline $\begin{array}{l}\text { Transmembrane protease serine } 2 \\
\text { (TMPRSS2) }\end{array}$ & Enzyme & Host protein & $\begin{array}{l}\text { Proteolytic cleavage to prime the spike protein-Ace2 } \\
\text { receptor interaction in viral fusion }\end{array}$ & {$[49,94,95]$} \\
\hline
\end{tabular}

Analysis of the genome sequences of the catalytic sites and key-drug binding sites of these enzymes suggest high degrees of sequence similarity with those from SARS and MERS coronaviruses. And thus, the known inhibitors of these enzymes from SARS and MERS coronaviruses could be repurposed for the possible treatments of COVID-19 [89].

Among these, the Spike protein of the coronavirus attaches to the angiotensin-converting enzyme 2 (ACE2) host receptor which facilitates the viral fusion and entry inside the host cell. So, the blocking of the interaction of the spike protein with the ACE2 receptor with specific inhibitor provides a strategy for potential antiviral development [90].

Both 3-chymotrypsin-like protease (3CL $\left.{ }^{\text {pro }}\right)$ and papainlike protease $\left(\mathrm{PL}^{\mathrm{pro}}\right)$ cleavesthe initially synthesized polyprotein complex required for the replication and transcription of the viral RNA [91].

The helicase of coronavirus possesses nucleotidetriphosphatase, duplex RNA/DNA-unwinding and RNAcapping activities that are essential for viral replication and proliferation and thus this enzyme is another attractive target for antiviral drug development against SARS-CoV-2 [92].

Coronavirus RNA-dependent RNA polymerase (RdRp) plays pivotal role in the viral replication and production of multiple copies of the viral genome. It also transcribes the subgenomic RNAs and mRNAs being located in the replicase complex [93].

Beside these, host cell membrane receptor protein and proteases i.e., ACE2 and TMPRSS2 have been proposed as the potential therapeutic targets against SARS-CoV-2 in few studies as these proteins are involved in ensuring the viral entry inside the host cell [94,95]. Thus, the understanding of molecular target and its role in pathogenesis is crucial for drug discovery. Research should be focused targeting different protein molecules to increase the confidence margin of SARS-CoV-2 antiviral drug development.

\section{THERAPEUTIC OPTIONS FOR COVID-19 TREATMENT}

\section{Antiviral Drugs and Other Candidate Molecules}

The development of drugs against SARS-CoV-2 has become an urgent necessity to combat the COVID-19 pandemic. With about $15 \%$ of COVID-19 patients suffering from severe disease and hospitals being overwhelmed, treatments are desperately needed in this situation. Although, there is no specific drug or vaccine available which can be used to treat the COVID-19till now, ranges of nonspecific drug have been proven effective to alleviate the COVID-19 condition [96].

A recent study has been carried on five FDA-approved drugs and two broad spectrum antiviral drugs to assess their inhibitory activities on SARS-CoV-2. Among these, Ribavirin (half-maximal effective concentration $\left.\left(\mathrm{EC}_{50}\right)=109.50 \mu \mathrm{M}\right)$, Penciclovir $\left(\mathrm{EC}_{50}=95.96 \mu \mathrm{M}\right)$ and Favipiravir $\left(\mathrm{EC}_{50}=61.88 \mu \mathrm{M}\right)$ were required at higher concentration to inhibit the virus. Nafamostat and Nitazoxanide were required at comparatively lower concentration with $\mathrm{EC}_{50}$ values of $22.50 \mu \mathrm{M}$ and $\mathrm{EC}_{50}=2.12 \mu \mathrm{M}$ but two compounds; Remdesivir $\left(\mathrm{EC}_{50}=0.77 \mu \mathrm{M}\right)$ and Chloroquine $\left(\mathrm{EC}_{50}=1.13 \mu \mathrm{M}\right)$ potently blocked virus infection at low-micromolar concentration (Table 4) [97].

Remdesivir was also shown to be effective in alleviating the COVID-19 condition of first infected person in USA and this drug is now on its phase III clinical trial on a check for COVID-19 treatment in China. A derivative of Chloroquine, Hydroxychloroquine is less toxic and shown to have comparable inhibitory effect as with Chloroquine and several trials on Hydroxychloroquine for COVID-19 treatment was initiated in China in February 2020 [98,99]. 
Pathogenesis, Diagnosis and Therapeutics for COVID-19

Table 4. Different drugs that were found to act against SARS-CoV-2 in different laboratory and clinical experiments. General information was retrieved from DrugBank [108]

\begin{tabular}{|c|c|c|c|c|c|}
\hline Drug Name & Category & $\begin{array}{l}\text { Mechanism of Action on } \\
\text { Viruses }\end{array}$ & Effects on SARS-CoV-2 & $\begin{array}{l}\text { Evidence on SARS- } \\
\text { CoV-2 }\end{array}$ & References \\
\hline Ribavirin & $\begin{array}{l}\text { Nucleoside analog, Antiviral } \\
\text { (Approved) }\end{array}$ & $\begin{array}{l}\text { Termination of viral mRNA } \\
\text { synthesis. }\end{array}$ & $\begin{array}{l}\text { Inhibits the virus with EC50 value } \\
\text { of } 109.50 \mu \mathrm{M} \text {. }\end{array}$ & In vitro experiment & {$[97]$} \\
\hline Penciclovir & $\begin{array}{l}\text { Nucleoside analog, Antiviral } \\
\text { (Approved) }\end{array}$ & $\begin{array}{l}\text { Interferes with viral replication } \\
\text { and transcription. }\end{array}$ & $\begin{array}{l}\text { Inhibits the virus with EC50 value } \\
\text { of } 95.96 \mu \mathrm{M} \text {. }\end{array}$ & In vitro experiment & [97] \\
\hline Favipiravir & $\begin{array}{l}\text { Antiviral, modified pyrazine } \\
\text { analog (Approved, } \\
\text { Investigational) }\end{array}$ & $\begin{array}{l}\text { Interferes with replication and } \\
\text { transcription by targeting RNA- } \\
\text { dependent RNA polymerase. }\end{array}$ & $\begin{array}{l}\text { Inhibits the virus with EC50 value } \\
\text { of } 61.88 \mu \mathrm{M} \text {. }\end{array}$ & In vitro experiment & [97] \\
\hline Nafamostat & $\begin{array}{l}\text { Serine protease inhibitor } \\
\text { (Investigational) }\end{array}$ & - & $\begin{array}{l}\text { Inhibits the virus with EC50 value } \\
\text { of } 22.50 \mu \mathrm{M} \text {. }\end{array}$ & In vitro experiment & [97] \\
\hline Nitazoxanide & $\begin{array}{l}\text { Antiprotozoal agent } \\
\text { (Approved, Investigational) }\end{array}$ & $\begin{array}{l}\text { Inhibits the replication of } \\
\text { several RNA and DNA viruses. }\end{array}$ & $\begin{array}{l}\text { Inhibits the virus with EC50 value } \\
\text { of } 2.12 \mu \mathrm{M} \text {. }\end{array}$ & In vitro experiment & [97] \\
\hline Remdesivir & $\begin{array}{l}\text { Antiviral, Nucleoside analog } \\
\text { (Investigational) }\end{array}$ & $\begin{array}{l}\text { Transcription termination by } \\
\text { inhibiting the activity of RNA } \\
\text { polymerase. }\end{array}$ & $\begin{array}{l}\text { Inhibits the virus with EC50 value } \\
\text { of } 0.77 \mu \mathrm{M} \text {. }\end{array}$ & $\begin{array}{l}\text { In vitro and clinical } \\
\text { experiment (Under } \\
\text { trial) }\end{array}$ & [97-99] \\
\hline Chloroquine & $\begin{array}{l}\text { Antimalarial drug, } \\
\text { (Approved, Investigational) }\end{array}$ & $\begin{array}{l}\text { Inhibits the terminal } \\
\text { glycosylation of Ace2 receptor. }\end{array}$ & $\begin{array}{l}\text { Inhibits the virus with EC50 value } \\
\text { of } 1.13 \mu \mathrm{M} \text {. }\end{array}$ & In vitro experiment. & {$[97]$} \\
\hline Hydroxychloroquine & $\begin{array}{l}\text { Antimalarial drug, } \\
\text { (Approved) }\end{array}$ & $\begin{array}{l}\text { Inhibits the terminal } \\
\text { glycosylation of Ace } 2 \text { receptor }\end{array}$ & Inhibits the virus effectively & $\begin{array}{l}\text { In vitro and clinical } \\
\text { experiment (Under } \\
\text { trial) }\end{array}$ & {$[98,99]$} \\
\hline Lopinavir & $\begin{array}{l}\text { Antiretroviral protease } \\
\text { inhibitor (Approved) }\end{array}$ & $\begin{array}{l}\text { Interferes with the viral } \\
\text { protease and results in the } \\
\text { production of immature and } \\
\text { non-infectious viral particles }\end{array}$ & $\begin{array}{l}\text { Blocks the SARS-CoV-2 replication } \\
\text { at } \mathrm{EC}_{50} \text { value of } 26.63 \mu \mathrm{M} \text {. }\end{array}$ & $\begin{array}{l}\text { In vitro and clinical } \\
\text { experiment (Under } \\
\text { trial) }\end{array}$ & {$[100]$} \\
\hline Homoharringtonine & $\begin{array}{l}\text { Protein synthesis inhibitor } \\
\text { (Approved, Investigational) }\end{array}$ & - & $\begin{array}{l}\text { Blocks the SARS-CoV-2 replication } \\
\text { at } \mathrm{EC}_{50} \text { value of } 2.55 \mu \mathrm{M} \text {. }\end{array}$ & In vitro experiment. & {$[100]$} \\
\hline Emetine & (Experimental) & - & $\begin{array}{l}\text { Blocks the SARS-CoV-2 replication } \\
\text { at } \mathrm{EC}_{50} \text { value of } 0.46 \mu \mathrm{M} \text {. }\end{array}$ & In vitro experiment. & {$[100]$} \\
\hline Ivermectin & $\begin{array}{l}\text { Anti-parasitic drug } \\
\text { (Approved, Investigational) }\end{array}$ & - & Blocks viral replication effectively. & In vitro experiment. & {$[100]$} \\
\hline $\begin{array}{l}\text {-D-N }{ }^{4}- \\
\text { hydroxycytidine }\end{array}$ & $\begin{array}{l}\text { Antiviral, Nucleoside analog } \\
\text { (Experimental) }\end{array}$ & $\begin{array}{l}\text { Induces mutation on RNA } \\
\text { viruses. }\end{array}$ & $\begin{array}{l}\text { Inhibits multiple bat } \\
\text { coronaviruses including SARS- } \\
\text { CoV-2, SARS-CoV and MERS-CoV. }\end{array}$ & In vitro experiment. & {$[101]$} \\
\hline Camostat mesylate & (Experimental) & - & $\begin{array}{l}\text { Blocks TMPRSS } 2 \text { and prevents } \\
\text { viral entry inside cell. }\end{array}$ & In vitro experiment. & [102] \\
\hline Ritonavir & $\begin{array}{l}\text { Antiviral, protease inhibitor } \\
\text { (Approved, Investigational) }\end{array}$ & Inhibits the viral replication. & $\begin{array}{l}\text { Alleviates the COVID-19 condition } \\
\text { in combination with Lopinavir. }\end{array}$ & $\begin{array}{l}\text { In vitro and clinical } \\
\text { experiment (Under } \\
\text { trial) }\end{array}$ & $\begin{array}{l}{[103,104,} \\
107]\end{array}$ \\
\hline
\end{tabular}

In yet another laboratory experiment, Remdesivir was shown to inhibit SARS-CoV-2 replication in Vero-E6 cells with $\mathrm{EC}_{50}$ at $23.15 \mu \mathrm{M}$. Moreover, Lopinavir, Homoharringtonine and Emetine were also shown to block the SARS-CoV-2 replication at $\mathrm{EC}_{50}$ values of 26.63, 2.55 and $0.46 \mu \mathrm{M}$, respectively in the same experiment [100]. Ivermectin, another FDA-approved drug is capable to inhibit the SARS-CoV-2 viral replication effectively [101]. Another recent study has shown that the ribonucleoside analog $\beta$-D$\mathrm{N}^{4}$-hydroxycytidine has antiviral activity not only against SARS-CoV-2 but also on other multiple bat coronaviruses including SARS and MERS coronaviruses. This analog is orally bioavailable and has increased potency against a coronavirus bearing resistance mutations to the nucleoside analog inhibitor Remdesivir [102].

SARS-CoV-2 infection of lung cells depends on cell membrane protease and Camostat mesylate, an inhibitor of
TMPRSS2, blocks SARS-CoV-2 infection of lung cells. This inhibitor is also effective to inhibit the SARS and MERS coronavirus entry inside the lung cell [103]. A clinical study suggested that the combination of Lopinavir and Ritonavir showed notable therapeutic benefits to COVID-19 patients compared to using pneumonia-associated adjuvant drug alone [104]. These two drugs are also being tested in clinical trials now although, another clinical experiment claimed that no benefits were observed in hospitalized COVID-19 patient beyond the standard care using the combined medication [105,106]. On March 20, 2020, World Health Organization (WHO) launched megatrials on four most promising drugs i.e., Chloroquine, Hydroxychloroquine, Remdesivir, and combination of Ritonavir and Lopinavir and the combination plus IFN- $\beta$ [107]. 


\section{Repurposing Options of Drugs and Other Candidates for SARS-CoV-2}

Drug repurposing is an effective drug discovery strategy from existing drugs, which could shorten the time and reduce the cost compared to de novo drug discovery. Since, different structural proteins and overall genome sequences of all three SARS-related coronaviruses have significant similarities and hence, it is logical that the drugs which work on previous two SARS-related coronaviruses might work on novel coronavirus as well [109].

For example, a potent MERS-CoV inhibitor, Nafamostat has recently been proven to also act against SARS-CoV-2. And thus, SARS-CoV 3CL ${ }^{\text {pro }}$ inhibitor i.e., 3-isotheaflavin-3gallate (IC50 $=7 \mu \mathrm{M}$ ) is also expected to inhibit SARS-CoV$23 \mathrm{CL}^{\text {pro }}[97,110]$. In another distinct experiment, different keto-glutamine analogs were proven to inhibit SARS-CoV $3 \mathrm{CL}^{\text {pro }}$ [111]. Another laboratory experiment on a series of flavonoid derivatives showed different Biflavonoids can have potential inhibitory effects on $3 \mathrm{CL}^{\text {pro }}$ of SARS-Cov-2. Among different Biflavonoids, Amentoflavone was reported to have better $3 \mathrm{CL}^{\text {pro }}$ inhibitory activity with $\mathrm{IC}_{50}$ value of $8.3 \mu \mathrm{M}$ [112].

Helicase is the enzyme responsible for the unwinding of double stranded nucleic acid complex during replication and the inhibition of this enzyme prevents the viral reproduction cycle. Study revealed that, Bannanin and its different derivatives i.e., Iodobananin, Vanillinbananin and Eubananin can significantly inhibit the helicase activity of SARS-CoV [113]. Nucleoside analogs inhibit the viral replication by incorporating inside the extending DNA strand during the viral DNA replication and terminate the replication process essential for viral life cycle. A nucleoside analog, $\beta-\mathrm{D}-\mathrm{N}^{4}$-hydroxycytidine was shown to inhibit the SARS-CoV viral replication with an approximated $\mathrm{EC}_{50}$ of 10 $\mu \mathrm{M}$ in a laboratory experiment [114].

$\mathrm{PL}^{\mathrm{pro}}$ is an enzyme which cleaves the initial polyprotein complex is a potential drug target for SARS-CoV-2. Different Tomentin derivatives were shown to inhibit the PL ${ }^{\text {pro }}$ enzyme with $\mathrm{IC}_{50}$ value ranging between 5.0 and $14.4 \mu \mathrm{M}$ [115].

Different drugs that were shown to be somewhat effective in laboratory experiments which require further evaluation in clinical trials. Although, drug repurposing provides few advantages over de novo drug discovery by reducing time and cost but few steps i.e., new dosage formulation can't be skipped which may take extra bit of time even in emergency cases. But, this could be an alternative way to get major attention for a viral disease when no vaccine is available.

\section{Therapeutic Monoclonal Antibody Preparation}

Native virions present the most poten immunogen or antigen to be used in immunization or monoclonal antibody preparation [116]. Coronavirus spike protein is the most antigenic protein which interacts with ACE2 receptor and this interaction mediates the viral entry inside the host cell as mentioned earlier. Monoclonal antibodies (mAbs) provide excellent therapeutic option to prevent the SARS-CoV viral entry inside the host cell by interfering with the ACE2-Spike protein interaction [117].

A SARS-CoV-specific human monoclonal antibody, CR3022, has been proven to bind the receptor binding domain (RBD) of SARS-CoV-2 spike protein in a recent laboratory experiment. This finding suggests that CR3022 alone or in combination with other antibodies could be potential therapeutic option for COVID-19 treatment [118]. F26G18 and F26G19 are two different antibodies which can effectively bind with RBD of SARS-CoV spike protein in vitro [119]. However, the RBD shows high rates of mutations and therefore, might escape the mAbs-mediated neutralization in some cases. Therefore, other antibodies which are specific to domains except RBD i.e., two conserved heptad repeats (i.e. HR1 and HR2) of Spike protein can provide better therapeutic benefits [120]. Moreover, S230 is another monoclonal antibody which has recently been shown to block the SARS-CoV viral entry inside the cell by blocking the interaction with $\mathrm{S} 1$ subunit of spike protein with the cell membrane receptor ACE2 [121].

Beside these, immune sera from convalescent patients have been shown to be effective in the treatment of patients infected with SARS-CoV-2 making passive immune therapy with human monoclonal antibodies an attractive treatment option for COVID-19. So, the simplest and most direct way based on mAbs therapeutic interventions to treat the COVID-19 patient would be to use the plasma from convalescent patients [122]. Thus, different mAbs could be used to alleviate the COVID-19 condition but how much alleviation is possible remains another concern to reconsider and the availability and management of the mAbs in accordance with demand imposes further challenge.

\section{Therapeutic Intervention with Interferon}

Recombinant human interferons were shown to be effective in treating SARS-CoV patient immediately after the SARS-CoV outbreak. IFN- $\beta$ was shown to be more effective in a laboratory experiment followed by IFN $-\gamma$ and interferon IFN- $\alpha$ in inhibiting viral replication in different cell lines [123]. In yet another in vitro study, IFN- $\beta$ 1a was shown to be effective to block SARS-CoV replication in Vero E- 6 cell line [124].

Falzarano et al. reported the efficacy of a combination containing IFN- $\alpha 2 \beta$ and Ribavirin on a novel $\beta$ coronavirus, $\mathrm{nCoV}$, as the causative agent of severe respiratory illness in humans originating in Saudi Arabia, Qatar and Jordan. They found both interferon- $\alpha 2 b$ and Ribavirin alone and their combination were effective to act against $\mathrm{nCoV}$ and thus blocking its infection. However, the combination of interferon- $a 2 b$ and Ribavirin together showed slightly better effect [125]. Conversely, SARS-CoV ORF 3b, ORF 6, and nucleocapsid proteins were reported to inhibit a key protein required to express IFN- $\beta$, IFN regulatory factor 3 (IRF-3) in host cell in a distinct in vitro study [126]. 
A recent study has suggested interferon $\beta$ as the most suited option for the treatment of COVID-19 and also SARSCoV-2 might have more sensitivity towards IFN than other SARS-related coronaviruses [127]. Another in vitro study about the effects of interferon on SARS-CoV and SARS$\mathrm{CoV}-2$ has found that the pretreatment of viral infected cells with type I interferon (IFN-I) resulted in much higher decrease in SARS-CoV-2 virus titer than that of SARS-CoV titer in 48 hours. A deficit in the viral nucleocapsid protein was observed after the treatment with IFN-I. The experiment also suggested that SARS-CoV-2 might be more sensitive to IFN-I treatment and this is might be due to the change in viral protein [128]. Thus, interferons could serve as an option to consider during very critical cases of COVID-19.

\section{RNA Interference}

RNA interference (RNAi) is a strategy that employs conserved biological response to double stranded RNA inside a host and is commonly used in post-transcriptional gene silencing [129]. This technique makes the use of 19-23 base pair double-stranded RNA to degrade targeted host RNA and inactivate its particular function in few specific and stepwise manners [130]. RNAi is commonly used to generate gene-knockouts and study gene function in different organisms. RNAi assisted inhibition of replication has been reported in many viruses including those that infect human in different studies [131].

RNAi technique was also studied extensively to inhibit different viral proteins of SARS-CoV in different laboratory experiments. It is capable of inhibiting the SARS-CoV spike protein encoding gene expression in HEK 293T cells as proven in in vitro experiment [132]. In another distinct laboratory experiment, designed small interfering RNA (siRNA) was directed against three subgenome RNA of SARS-CoV. Significant reduction in the expression of the targeted RNAs was observed without interfering the expression of other RNAs [133]. The SARS-CoV viral replication can be effectively reduced as evident with $85-90 \%$ reduction in viral genome RNA using siRNA-based RNAi technology in vero E6 cells in laboratory experiment [134].

Moreover, a previous study carried out on animal model using rhesus macaque (Macaca mulatta) showed significant improvement in SARS-severity in the subject animals rather than the controls upon siRNA-based therapy [135]. Although, this technique seems to be effective to block few viruses but as advanced technique it may face difficulties with availability of expertise, sophisticated equipment and pricing which may opt it out from consideration of use to treat COVID-19.

\section{Vaccine}

Vaccination is one of the most efficient ways to prevent viral diseases which has been used from the very past. A vaccine helps boosting the body's immune system in order to recognize and fight different pathogens like viruses or bacteria, which then keeps us safe from the diseases they cause [136]. With no specific antiviral drug and specific vaccine for COVID-19, the development of such one is urgently required but it would take a significant period of time due to longer clinical trial and other processes. Moreover, there are significant hurdles to overcome during the development of vaccine against SARS-CoV i.e., immunopotentiation in the form of eosinophilic infiltration or increased infectivity, target population on which the vaccine will work and the mutation rate of the virus.

There are different types of vaccines i.e., live vaccines, attenuated vaccines, Inactivated/killed vaccines, Subunit and conjugate vaccines, Toxoid vaccines [137]. In the case of COVID-19, 79 vaccine candidates are in active development (confirmed as of early April 2020), 74 were not yet in human evaluation with only five in phase I clinical trial.

Coalition for Epidemic Preparedness Innovations (CEPI) scientists reported in April, 2020 that, 115 total vaccine candidates were in early stages of development, with 78 confirmed as active projects (79, according to the Milken Institute), and 37 others announced, but little public information available was available for those (presumed to be in planning or being designed) $[138,139]$.

Phase I-II randomized, interventional trials for safety assessment and dosage formulation began in Wuhan, China on the candidate vaccine, Ad5-nCoV (CanSino Biologics) [140], and in England on the candidate, ChAdOx1 nCoV-19 [141]. Table 5 and 6 enlist most updated information about the vaccine development progresses in clinical and preclinical phases in different companies and industries. Phase I trials check an investigated therapeutic primarily for its safety and preliminary dosing in a few number of healthy subjects, while Phase II trials, evaluate effective dose levels and side effects of the candidate vaccine in dozens-tohundreds of people either with the targeted disease or in healthy subjects following the success of Phase I clinical trial. A Phase I-II trial conducts preliminary safety and dosing testing, is typically randomized, placebo-controlled, and at multiple sites, while determining more precise, effective doses [142]. Therefore, due to the extended period of clinical phases and additional manufacturing steps, it will certainly take a while for the vaccines to be available in the market. And again, the massive production, availability to people from all countries, price are some other concerns. Therefore, strategy to develop antiviral is urgent to continue in parallel with vaccine trials.

\section{CONCLUDING REMARKS}

After transmission to human body the virus fist enters the targeted cells of host where they carry out replication and produce multiple copies of the virus. Then newly assembled virions then lyse the host cells and continue to infect new healthy cells which characterize the pathogenesis. The knowledge of pathogenesis may help to understand the necessity of preventive measures, basis of diagnosis and possible therapeutic options. Early diagnosis of the infected 
Pathogenesis, Diagnosis and Therapeutics for COVID-19

Table 5. Vaccine candidates under clinical trial for COVID-19

\begin{tabular}{|c|c|c|c|c|c|}
\hline Candidate & Characteristics & Developer & Current Status & $\begin{array}{l}\text { Same Platform for non- } \\
\text { coronavirus Candidate }\end{array}$ & References \\
\hline \multirow[t]{2}{*}{ Ad5-nCoV } & \multirow[t]{2}{*}{$\begin{array}{l}\text { Adenovirus type } 5 \text { vector expressing } S \\
\text { protein }\end{array}$} & \multirow[t]{2}{*}{ CanSino Biologics } & $\begin{array}{l}\text { Phase-1 } \\
\text { (NCT04313127) }\end{array}$ & Ebola & [143-146] \\
\hline & & & $\begin{array}{l}\text { Phase-2 } \\
\text { (NCT04341389) }\end{array}$ & & \\
\hline ChAdOx1 nCoV-19 & $\begin{array}{l}\text { An attenuated adenovirus capable of } \\
\text { producing the S protein of SARS-CoV-2 } \\
\text { that permits for the formation of } \\
\text { endogenous antibodies against these } \\
\text { proteins }\end{array}$ & University of Oxford & $\begin{array}{l}\text { Phase-1 } \\
\text { (NCT04324606) }\end{array}$ & $\begin{array}{l}\text { MERS, Influenza, TB, } \\
\text { Chikungunya, Zika, } \\
\text { MenB, Plague }\end{array}$ & $\begin{array}{l}{[143,147,} \\
148]\end{array}$ \\
\hline mRNA-1273 & $\begin{array}{l}\text { LNP-encapsulated mRNA vaccine that } \\
\text { encodes } \mathrm{S} \text { protein }\end{array}$ & Moderna & $\begin{array}{l}\text { Phase-1 } \\
\text { (NCT04283461) }\end{array}$ & Multiple Candidates & $\begin{array}{l}{[143,149,} \\
150]\end{array}$ \\
\hline Covid-19/aAPC & $\begin{array}{l}\text { aAPCs modified with lentiviral vector } \\
\text { which expresses synthetic minigene } \\
\text { based on domains of selected viral } \\
\text { proteins }\end{array}$ & $\begin{array}{l}\text { Shenzhen Geno-Immune } \\
\text { Medical Institute }\end{array}$ & $\begin{array}{l}\text { Phase-1 } \\
\text { (NCT04299724) }\end{array}$ & - & [151] \\
\hline LV-SMENP-DC & $\begin{array}{l}\text { DCs modified with lentiviral vector } \\
\text { expressing synthetic minigene based on } \\
\text { domains of selected viral proteins and } \\
\text { directed with antigen-specific CTLs }\end{array}$ & $\begin{array}{l}\text { Shenzhen Geno-Immune } \\
\text { Medical Institute }\end{array}$ & $\begin{array}{l}\text { Phase-1 } \\
\text { (NCT04276896) }\end{array}$ & - & [152] \\
\hline INO-4800 & $\begin{array}{l}\text { Electroporation delievers DNA plasmid } \\
\text { encoding S protein }\end{array}$ & Inovio Pharmaceuticals & $\begin{array}{l}\text { Phase-1 } \\
\text { (NCT04336410) }\end{array}$ & $\begin{array}{l}\text { Lassa, Nipah,HIV, Filovirus, } \\
\text { HPV, Cancer indications, } \\
\text { Zika, Hepatitis B }\end{array}$ & $\begin{array}{l}{[143,153,} \\
154]\end{array}$ \\
\hline
\end{tabular}

Table 6. Selected vaccine candidates under preclinical research for COVID-19

\begin{tabular}{|c|c|c|c|c|c|}
\hline Candidate Type & Platform & Developer & Current Status & $\begin{array}{l}\text { Same Platform for non- } \\
\text { coronavirus Candidate }\end{array}$ & References \\
\hline $\begin{array}{l}\text { DNA with } \\
\text { electroporation }\end{array}$ & DNA & $\begin{array}{l}\text { Karolinska Institute / } \\
\text { Cobra Biologics } \\
\text { (OPENCORONA Project) }\end{array}$ & Pre-Clinical & - & [155-157] \\
\hline DNA plasmid Vaccine & DNA & Zydus Cadila & Pre-Clinical & & {$[158,159]$} \\
\hline $\begin{array}{l}\text { adenovirus-based } \\
\text { NasoVAX expressing } \\
\text { SARS2-CoV spike } \\
\text { protein }\end{array}$ & Non-Replicating Viral Vector & Altimmune & Pre-Clinical & Influenza & {$[160-163]$} \\
\hline DNA plasmid Vaccine & DNA & $\begin{array}{l}\text { Osaka University/ AnGes/ } \\
\text { Takara Bio }\end{array}$ & Pre-Clinical & - & {$[164,165]$} \\
\hline $\begin{array}{l}\text { S protein (baculovirus } \\
\text { production) }\end{array}$ & Protein Subunit & Sanofi Pasteur & Pre-Clinical & Influenza, SARS-CoV & [166] \\
\hline $\begin{array}{l}\text { LNP-encapsulated } \\
\text { mRNA encoding RBD }\end{array}$ & RNA & $\begin{array}{l}\text { Fudan } \\
\text { University/Shanghai } \\
\text { JiaoTong } \\
\text { University/RNACure } \\
\text { Biopharma }\end{array}$ & Pre-Clinical & - & [167] \\
\hline Measles Vector & Replicating Viral Vector & $\begin{array}{l}\text { Institute Pasteur / } \\
\text { Themis / Univ. of } \\
\text { Pittsburg Center for } \\
\text { Vaccine Research }\end{array}$ & Pre-Clinical & $\begin{array}{l}\text { West nile, chik, } \\
\text { Ebola, Lassa, Zika }\end{array}$ & {$[168,169]$} \\
\hline $\begin{array}{l}\text { Recombinant protein, } \\
\text { nanoparticles (based } \\
\text { on S- protein and other } \\
\text { epitopes) }\end{array}$ & Protein Subunit & $\begin{array}{l}\text { Saint-Petersburg } \\
\text { scientific research } \\
\text { institute of vaccines and } \\
\text { serums }\end{array}$ & Pre-Clinical & - & [170-172] \\
\hline $\begin{array}{l}\text { MVA expressing } \\
\text { structural proteins }\end{array}$ & Non-Replicating Viral Vector & $\begin{array}{l}\text { Centro Nacional } \\
\text { Biotecnología (CNB-CSIC), } \\
\text { Spain }\end{array}$ & Pre-Clinical & $\begin{array}{l}\text { HIV, HCV, chikungunya, } \\
\text { Ebola, zika, malaria, } \\
\text { leishmania }\end{array}$ & [173] \\
\hline $\begin{array}{l}\text { Plasmid DNA, Needle- } \\
\text { Free Delivery }\end{array}$ & DNA & $\begin{array}{l}\text { Immunomic } \\
\text { Therapeutics, } \\
\text { Inc./EpiVax, } \\
\text { Inc./PharmaJet, Inc. }\end{array}$ & Pre-Clinical & SARS & {$[174,175]$} \\
\hline
\end{tabular}


patient and isolation is a prerequisite to combat the outbreak of any contagious viral pathogen. Diagnosis of the SARS$\mathrm{CoV}-2$ virus can be achieved in variety of means which vary depending on the types of samples used and involve ranges of advantages and disadvantages. Although, no specific therapeutic option is currently available which can be used to effective treat COVID-19, many approaches have been taken recently and few of those are under clinical trial now. Different candidate molecules, drugs and other preparations have already shown positive responses against SARS-CoV-2 but these are not clinically proven and hence need further evaluation. Of course, a definitive cure which can help patients recover will be available soon.

\section{ACKNOWLEDGEMENT}

Authors acknowledge the members of Swift Integrity Computational Lab, Dhaka, Bangladesh, a virtual platform of young researchers for their support during the preparation of the manuscript.

Declaration of interest: The authors report no conflicts of interest. Financial Disclosure: No financial support was received.

\section{REFERENCES}

1. Moin AT, Sakib MN, Araf Y, Sarkar B, Ullah MA. Combating COVID-19 Pandemic in Bangladesh: A Memorandum from Developing Country. Preprints. 2020 May 27.

2. Lu R, Zhao X, Li J, Niu P, Yang B, Wu H, et al. Genomic characterisation and epidemiology of 2019 novel coronavirus: implications for virus origins and receptor binding. Lancet, 2020;395(10224):565-74. doi: 10.1016/S0140-6736(20)30251-8.

3. Zhang L, Shen FM, Chen F, Lin Z. Origin and evolution of the 2019 novel coronavirus. Clinical infectious diseases, 2020;71(15):882-3. doi: 10.1093/cid/ciaa112.

4. Perlman S. Another Decade, Another Coronavirus. N Engl J Med. 2020 Feb 20;382(8):760-2. doi: 10.1056/NEJMe2001126.

5. Kelly-Cirino C, Mazzola LT, Chua A, Oxenford CJ, Van Kerkhove MD. An updated roadmap for MERS-CoV research and product development: focus on diagnostics. BMJ global health. 2019;4(Suppl 2):e001105. doi: 10.1136/bmjgh-2018-001105.

6. Euro.who.int. 2020. WHO Announces COVID-19 Outbreak A Pandemic. Available at: http://www.euro. who.int/en/health-topics/health-emergencies/coronavir us-covid-19/news/news/2020/3/who-announces-covid19-outbreak-a-pandemic (Accessed: 13 April 2020).

7. Zumla A, Chan JF, Azhar EI, Hui DS, Yuen KY. Coronaviruses - drug discovery and therapeutic options. Nat Rev Drug Discov. 2016;15(5):327-47. doi: 10.1038/nrd.2015.37.
8. Chan JF, Lau SK, Woo PC. The emerging novel Middle East respiratory syndrome coronavirus: the "knowns" and "unknowns". J Formos Med Assoc. 2013;112(7):372-81. doi: 10.1016/j.jfma.2013.05.010.

9. Zhu Y, Li C, Chen L, Xu B, Zhou Y, Cao L, Shang Y, Fu Z, Chen A, Deng L, Bao Y. A novel human coronavirus OC43 genotype detected in mainland China. Emerging microbes \& infections. 2018 Dec 1;7(1):1-4. doi: 10.1038/s41426-018-0171-5.

10. Cheng VC, Lau SK, Woo PC, Yuen KY. Severe acute respiratory syndrome coronavirus as an agent of emerging and reemerging infection. Clin Microbiol Rev. 2007;20(4):660-94. doi: 10.1128/CMR.00023-07.

11. Chan JF, Lau SK, To KK, Cheng VC, Woo PC, Yuen KY. Middle East respiratory syndrome coronavirus: another zoonotic betacoronavirus causing SARS-like disease. Clin Microbiol Rev. 2015;28(2):465-522. doi: 10.1128/CMR.00102-14.

12. Liu J, Zheng $X$, Tong Q, et al. Overlapping and discrete aspects of the pathology and pathogenesis of the emerging human pathogenic coronaviruses SARS-CoV, MERS-CoV, and 2019-nCoV. J Med Virol. 2020;92(5):491-4. doi: 10.1002/jmv.25709.

13. Worldometers.info. 2020. Coronavirus Update (Live): 1,699,631 Cases And 102,734 Deaths From COVID-19 Virus Pandemic - Worldometer. Available at: https://www.worldometers.info/coronavirus/

(Accessed: 11 April 2020).

14. Jiang S, Shi Z, Shu Y, Song J, Gao GF, Tan W, Guo D. A distinct name is needed for the new coronavirus. The Lancet. 2020 Mar 21;395(10228):949. doi: 10.1016/S0140-6736(20)30419-0.

15. Lillie PJ, Samson A, Li A, Adams K, Capstick R, Barlow GD, Easom N, Hamilton E, Moss PJ, Evans A, Ivan M. Novel coronavirus disease (Covid-19): the first two patients in the UK with person to person transmission. Journal of Infection. 2020 Feb 28;80(5):578-606. doi: 10.1016/j.jinf.2020.02.020.

16. Wu F, Zhao S, Yu B. A new coronavirus associated with human respiratory disease in China [Published on February 03, 2020]. Nature 2020;579:265-9.

17. Gorbalenya AE, Baker SC, Baric RS, de Groot RJ, Drosten C, Gulyaeva AA, Haagmans BL, Lauber C, Leontovich AM, Neuman BW, Penzar D. The species severe acute respiratory syndrome related coronavirus: classifying 2019-nCoV and naming it SARS-CoV-2. Nat Microbiol 5: 536-544.

18. Wan Y, Shang J, Graham R, Baric RS, Li F. Receptor recognition by the novel coronavirus from Wuhan: an analysis based on decade-long structural studies of SARS coronavirus. Journal of virology. 2020 Mar 17;94(7): e00127-20. doi: 10.1128/JVI.00127-20. 
19. Walls AC, Park YJ, Tortorici MA, Wall A, McGuire AT, Veesler D. Structure, function, and antigenicity of the SARS-CoV-2 spike glycoprotein. Cell. 2020 Mar 9;181(2):281-92. doi: 10.1101/2020.02.19.956581.

20. Berry JD, Jones S, Drebot MA, Andonov A, Sabara M, Yuan XY, Weingartl H, Fernando L, Marszal P, Gren J, Nicolas B. Development and characterisation of neutralising monoclonal antibody to the SARScoronavirus. Journal of virological methods. 2004 Sep 1;120(1):87-96. doi: 10.1016/j.jviromet.2004.04.009.

21. Ma J. Coronavirus: China’s first confirmed Covid-19 case traced back to November 17. South China Morning Post. 2020 Mar;13. Available at: https://www.scmp.com/ news/china/society/article/3074991/coronaviruschinas-first-confirmed-covid-19-case-traced-back

22. Cohen J. Wuhan seafood market may not be source of novel virus spreading globally. Science. 2020 Jan 26;10. doi: 10.1126/science.abb0611.

23. Andersen KG, Rambaut A, Lipkin WI, Holmes EC, Garry RF. The proximal origin of SARS-CoV-2. Nature Medicine. 2020 Mar 17:1-3. doi: 10.1038/s41591-0200820-9.

24. Eschner K. We're still not sure where the Wuhan coronavirus really came from. Popular Science. Popular Science; 2020. Available at: https://www.popsci.com/ story/health/wuhan-coronavirus-china-wet-marketwild-animal/

25. Countries where COVID-19 has spread. Worldometer. Available at: https://www.worldometers.info/corona virus/countries-where-coronavirus-has-spread/

26. Corman VM, Landt O, Kaiser M, Molenkamp R, Meijer A, Chu DK, Bleicker T, Brünink S, Schneider J, Schmidt ML, Mulders DG. Detection of 2019 novel coronavirus (2019-nCoV) by real-time RT-PCR. Eurosurveillance. 2020 Jan 23;25(3):pii=2000045. doi: 10.2807/15607917.ES.2020.25.3.2000045.

27. Ngandu $T$, Lehtisalo J, Solomon A, Levälahti E, Ahtiluoto S, Antikainen R, Bäckman L, Hänninen T, Jula A, Laatikainen T, Lindström J. A 2 year multidomain intervention of diet, exercise, cognitive training, and vascular risk monitoring versus control to prevent cognitive decline in at-risk elderly people (FINGER): a randomised controlled trial. The Lancet. 2015 Jun 6;385(9984):2255-63. doi: 10.1016/S01406736(15)60461-5.

28. Yu WB, Tang GD, Zhang L, Corlett RT. Decoding the evolution and transmissions of the novel pneumonia coronavirus (SARS-CoV-2) using whole genomic data. ChinaXiv. 2020;202002:v2.

29. Benvenuto D, Giovanetti M, Ciccozzi A, Spoto S, Angeletti S, Ciccozzi M. The 2019-new coronavirus epidemic: evidence for virus evolution. Journal of Medical Virology. 2020 Apr;92(4):455-9. doi: 10.1002/jmv.25688.
30. Cui J, Li F, Shi ZL. Origin and evolution of pathogenic coronaviruses. Nature reviews Microbiology. 2019 Mar;17(3):181-92. doi: 10.1038/s41579-018-0118-9.

31. Bat SARS-like coronavirus isolate bat-SL-CoVZXC21, complete genome - Nucleotide - NCBI. National Center for Biotechnology Information. U.S. National Library of Medicine [cited: 12 April 2020]. Available at: https://www.ncbi.nlm.nih.gov/nuccore/MG772934

32. Han Y, Du J, Su H, Zhang J, Zhu G, Zhang S, Wu Z, Jin Q. Identification of diverse bat alphacoronaviruses and betacoronaviruses in China provides new insights into the evolution and origin of coronavirus-related diseases. Frontiers in microbiology. 2019;10:1900.

33. Bat coronavirus RaTG13, complete genome - Nucleotide - NCBI. National Center for Biotechnology Information. U.S. National Library of Medicine; [Cited: 12 April 2020]. Available at: https://www.ncbi.nlm.nih.gov/ nuccore/1802633852

34. Kolifarhood G, Aghaali M, Saadati HM, Taherpour N, Rahimi S, Izadi N, Nazari SS. Epidemiological and Clinical Aspects of COVID-19; a Narrative Review. Archives of Academic Emergency Medicine. 2020;8(1):e41.

35. Lu R, Zhao X, Li J, Niu P, Yang B, Wu H, Wang W, Song $\mathrm{H}$, Huang B, Zhu N, Bi Y. Genomic characterisation and epidemiology of 2019 novel coronavirus: implications for virus origins and receptor binding. The Lancet. 2020 Feb 22;395(10224):565-74. doi: 10.1016/S01406736(20)30251-8.

36. Letko M, Marzi A, Munster V. Functional assessment of cell entry and receptor usage for SARS-CoV-2 and other lineage B betacoronaviruses. Nature microbiology. 2020 Apr;5(4):562-9. doi: 10.1038/s41564-020-0688-y.

37. Sheahan T, Rockx B, Donaldson E, Sims A, Pickles R, Corti D, Baric R. Mechanisms of zoonotic severe acute respiratory syndrome coronavirus host range expansion in human airway epithelium. Journal of virology. 2008 Mar 1;82(5):2274-85. doi: 10.1128/JVI.02041-07.

38. Cyranoski D. Mystery deepens over animal source of coronavirus. Nature. 2020 Mar 1;579(7797):18-9. doi: 10.1038/d41586-020-00548-w.

39. Xiao K, Zhai J, Feng Y, Zhou N, Zhang X, Zou JJ, Li N, Guo Y, Li X, Shen X, Zhang Z. Isolation and characterization of 2019-nCoV-like coronavirus from Malayan pangolins. BioRxiv. 2020 Jan 1. doi: 10.1101/2020.02.17.951335.

40. Zhang $\mathrm{T}, \mathrm{Wu} \mathrm{Q}$, Zhang Z. Probable pangolin origin of SARS-CoV-2 associated with the COVID-19 outbreak. Current Biology. 2020 Mar 19. doi: 10.1016/j.cub.2020.03.063.

41. Liu P, Chen W, Chen JP. Viral Metagenomics Revealed Sendai Virus and Coronavirus Infection of Malayan Pangolins (Manis javanica). Viruses. 2019 Nov;11(11):979. doi: 10.3390/v11110979. 
42. Wu A, Peng Y, Huang B, Ding X, Wang X, Niu P, Meng J, Zhu Z, Zhang Z, Wang J, Sheng J. Genome composition and divergence of the novel coronavirus (2019-nCoV) originating in China. Cell host \& microbe. 2020 Feb 7. doi: 10.1016/j.chom.2020.02.001

43. Weiss SR, Leibowitz JL. Coronavirus pathogenesis. InAdvances in virus research 2011 Jan 1 (Vol. 81, pp. 85164). Academic Press. doi: 10.1016/B978-0-12-3858856.00009-2.

44. Phelan AL, Katz R, Gostin LO. The novel coronavirus originating in Wuhan, China: challenges for global health governance. Jama. 2020 Feb 25;323(8):709-10. doi: 10.1001/jama.2020.1097.

45. WHO. How does COVID-19 Spread? Available at: https://www.who.int/news-room/q-a-detail/q-acoronaviruses

46. Jin YH, Cai L, Cheng ZS, Cheng H, Deng T, Fan YP, Fang C, Huang D, Huang LQ, Huang Q, Han Y. A rapid advice guideline for the diagnosis and treatment of 2019 novel coronavirus (2019-nCoV) infected pneumonia (standard version). Military Medical Research. 2020 Dec $1 ; 7(1): 4$.

47. Wu D, Wu T, Liu Q, Yang Z. The SARS-CoV-2 outbreak: what we know. International Journal of Infectious Diseases. 2020 Mar 12;94:44-8. doi: 10.1016/j.ijid.2020.03.004.

48. Yan R, Zhang Y, Li Y, Xia L, Guo Y, Zhou Q. Structural basis for the recognition of SARS-CoV-2 by full-length human ACE2. Science. 2020 Mar 27;367(6485):1444-8. doi: 10.1126/science.abb2762.

49. Glowacka I, Bertram S, Müller MA, Allen P, Soilleux E, Pfefferle S, Steffen I, Tsegaye TS, He Y, Gnirss K, Niemeyer D. Evidence that TMPRSS2 activates the severe acute respiratory syndrome coronavirus spike protein for membrane fusion and reduces viral control by the humoral immune response. Journal of virology. 2011 May 1;85(9):4122-34. doi: 10.1128/JVI.02232-10.

50. Xu X, Chen P, Wang J, Feng J, Zhou H, Li X, Zhong W, Hao P. Evolution of the novel coronavirus from the ongoing Wuhan outbreak and modeling of its spike protein for risk of human transmission. Science China Life Sciences. 2020 Mar;63(3):457-60. doi: 10.1007/s11427-020-1637-5.

51. Islam H, Rahman A, Masud J, Shweta DS, Araf Y, Ullah MA, Sium SM, Sarkar B. A Generalized Overview of SARS-CoV-2: Where Does the Current Knowledge Stand?. Electron J Gen Med. 2020; 17 (6): em251.

52. Namy O, Moran SJ, Stuart DI, Gilbert RJ, Brierley I. A mechanical explanation of RNA pseudoknot function in programmed ribosomal frameshifting. Nature. 2006 May;441(7090):244-7. doi: 10.1038/nature04735.

53. Ziebuhr J, Snijder EJ, Gorbalenya AE. Virus-encoded proteinases and proteolytic processing in the Nidovirales. Journal of General Virology. 2000 Apr 1;81(4):853-79. doi: 10.1099/0022-1317-81-4-853.
54. Sawicki SG, Sawicki DL, Siddell SG. A contemporary view of coronavirus transcription. Journal of virology. 2007 Jan 1;81(1):20-9. doi: 10.1128/JVI.01358-06.

55. Perlman S, Netland J. Coronaviruses post-SARS: update on replication and pathogenesis. Nature reviews microbiology. 2009 Jun;7(6):439-50. doi: 10.1038 /nrmicro2147.

56. Iqbal HM, Romero-Castillo KD, Bilal M, Parra-Saldivar R. The Emergence of Novel-Coronavirus and its Replication Cycle-An Overview. Journal of Pure and Applied Microbiology. 2020;14(1). doi: 10.22207/JPAM.14.1.03.

57. Nelemans T, Kikkert M. Viral Innate Immune Evasion and the Pathogenesis of Emerging RNA Virus Infections. Viruses. 2019 Oct;11(10):961. doi: 10.3390/v11100961.

58. Fehr AR, Channappanavar R, Perlman S. Middle East respiratory syndrome: emergence of a pathogenic human coronavirus. Annual review of medicine. 2017 Jan 14;68:387-99. doi: 10.1146/annurev-med-051215031152 .

59. Newton AH, Cardani A, Braciale TJ. The host immune response in respiratory virus infection: balancing virus clearance and immunopathology. In Seminars in immunopathology 2016 Jul 1 (Vol. 38, No. 4, pp. 471482). Springer Berlin Heidelberg. doi: 10.1007/s00281016-0558-0.

60. Michalovich D, Rodriguez-Perez N, Smolinska S, Pirozynski M, Mayhew D, Uddin S, Van Horn S, Sokolowska M, Altunbulakli C, Eljaszewicz A, Pugin B. Obesity and disease severity magnify disturbed microbiome-immune interactions in asthma patients. Nature communications. 2019 Dec 13;10(1):1-4. doi: 10.1038/s41467-019-13751-9.

61. Cheung CY, Poon LL, Ng IH, Luk W, Sia SF, Wu MH, Chan KH, Yuen KY, Gordon S, Guan Y, Peiris JS. Cytokine responses in severe acute respiratory syndrome coronavirus-infected macrophages in vitro: possible relevance to pathogenesis. Journal of virology. 2005 Jun 15;79(12):7819-26. doi: 10.1128/JVI.79.12.7819-7826.2005.

62. Law HK, Cheung CY, Ng HY, Sia SF, Chan YO, Luk W, Nicholls JM, Peiris JM, Lau YL. Chemokine upregulation in sars-coronavirus-infected, monocytederived human dendritic cells. Blood. 2005 Oct 1;106(7):2366-74. doi: 10.1182/blood-2004-10-4166.

63. Chien JY, Hsueh PR, Cheng WC, Yu CJ, Yang PC. Temporal changes in cytokine/chemokine profiles and pulmonary involvement in severe acute respiratory syndrome. Respirology. 2006 Nov;11(6):715-22. doi: 10.1111/j.1440-1843.2006.00942.x. 
64. Wang CH, Liu CY, Wan YL, Chou CL, Huang KH, Lin HC, Lin SM, Lin TY, Chung KF, Kuo HP. Persistence of lung inflammation and lung cytokines with highresolution CT abnormalities during recovery from SARS. Respiratory research. 2005 Dec 1;6(1):42. doi: 10.1186/1465-9921-6-42.

65. Wong CK, Lam CW, Wu AK, Ip WK, Lee NL, Chan IH, Lit LC, Hui DS, Chan MH, Chung SS, Sung JJ. Plasma inflammatory cytokines and chemokines in severe acute respiratory syndrome. Clinical \& Experimental Immunology. 2004 Apr;136(1):95-103. doi: 10.1111/j.1365-2249.2004.02415.x.

66. Zhang Y, Li J, Zhan Y, Wu L, Yu X, Zhang W, Ye L, Xu S, Sun R, Wang Y, Lou J. Analysis of serum cytokines in patients with severe acute respiratory syndrome. Infection and immunity. 2004 Aug 1;72(8):4410-5. doi: 10.1128/IAI.72.8.4410-4415.2004.

67. Tynell J, Westenius V, Rönkkö E, Munster VJ, Melén K, Österlund P, Julkunen I. Middle East respiratory syndrome coronavirus shows poor replication but significant induction of antiviral responses in human monocyte-derived macrophages and dendritic cells. The Journal of general virology. 2016 Feb 1;97(Pt 2):344. doi: 10.1099/jgv.0.000351.

68. Zhou J, Chu H, Li C, Wong BH, Cheng ZS, Poon VK, Sun T, Lau CC, Wong KK, Chan JY, Chan JF. Active replication of Middle East respiratory syndrome coronavirus and aberrant induction of inflammatory cytokines and chemokines in human macrophages: implications for pathogenesis. The Journal of infectious diseases. 2014 May 1;209(9):1331-42. doi: 10.1093/infdis/jit504.

69. Kim ES, Choe PG, Park WB, Oh HS, Kim EJ, Nam EY, $\mathrm{Na}$ SH, Kim M, Song KH, Bang JH, Park SW. Clinical progression and cytokine profiles of Middle East respiratory syndrome coronavirus infection. Journal of Korean medical science. 2016 Nov 1;31(11):1717-25. doi: 10.3346/jkms.2016.31.11.1717.

70. Min CK, Cheon S, Ha NY, Sohn KM, Kim Y, Aigerim A, Shin HM, Choi JY, Inn KS, Kim JH, Moon JY. Comparative and kinetic analysis of viral shedding and immunological responses in MERS patients representing a broad spectrum of disease severity. Scientific reports. 2016 May 5;6(1):1-2. doi: 10.1038/srep25359.

71. Pedersen SF, Ho YC. SARS-CoV-2: a storm is raging. The Journal of clinical investigation. 2020 Apr 13;130(5).

72. Yang Y, Shen C, Li J, Yuan J, Yang M, Wang F, Li G, Li Y, Xing L, Peng L, Wei J. Exuberant elevation of IP-10, MCP-3 and IL-1ra during SARS-CoV-2 infection is associated with disease severity and fatal outcome. MedRxiv. 2020 Jan 1.
73. Huang C, Wang Y, Li X, Ren L, Zhao J, Hu Y, Zhang L, Fan G, Xu J, Gu X, Cheng Z. Clinical features of patients infected with 2019 novel coronavirus in Wuhan, China. The Lancet. 2020 Feb 15;395(10223):497-506. doi: 10.1016/S0140-6736(20)30183-5.

74. Chen N, Zhou M, Dong X, Qu J, Gong F, Han Y, Qiu Y, Wang J, Liu Y, Wei Y, Yu T. Epidemiological and clinical characteristics of 99 cases of 2019 novel coronavirus pneumonia in Wuhan, China: a descriptive study. The Lancet. $\quad 2020$ Feb 15;395(10223):507-13. doi: 10.1016/S0140-6736(20)30211-7.

75. Pfefferle S, Reucher S, Nörz D, Lütgehetmann M. Evaluation of a quantitative RT-PCR assay for the detection of the emerging coronavirus SARS-CoV-2 using a high throughput system. Eurosurveillance. 2020 Mar 5;25(9). doi: 10.2807/1560-7917.ES.2020.25.9. 2000152.

76. Sarkar B, Ullah MA, Johora FT, Taniya MA, Araf Y. Immunoinformatics-guided designing of epitope-based subunit vaccine against the SARS Coronavirus-2 (SARSCoV-2). Immunobiology. 2020 May 11:151955.

77. Xie C, Jiang L, Huang G, Pu H, Gong B, Lin H, Ma S, Chen X, Long B, Si G, Yu H. Comparison of different samples for 2019 novel coronavirus detection by nucleic acid amplification tests. International Journal of Infectious Diseases. 2020 Feb 27;93:264-7. doi: 10.1016/j.ijid.2020.02.050.

78. To KK, Tsang OT, Yip CC, Chan KH, Wu TC, Chan JM, Leung WS, Chik TS, Choi CY, Kandamby DH, Lung DC. Consistent detection of 2019 novel coronavirus in saliva. Clinical infectious diseases: an official publication of the Infectious Diseases Society of America. 2020 Feb 12;71(15):841-3. doi: 10.1093/cid/ciaa149.

79. Al-Tawfiq JA, Memish ZA. Diagnosis of SARS-CoV-2 Infection based on CT scan vs. RT-PCR: Reflecting on Experience from MERS-CoV. Journal of Hospital Infection. $\quad 2020 \quad$ Mar 6;105(2):154-5. doi: 10.1016/j.jhin.2020.03.001.

80. Pan Y, Guan H, Zhou S, Wang Y, Li Q, Zhu T, Hu Q, Xia L. Initial CT findings and temporal changes in patients with the novel coronavirus pneumonia (2019-nCoV): a study of 63 patients in Wuhan, China. European radiology. 2020 Feb 13:1-4. doi: 10.1007/s00330-02006731-x.

81. Zhang JJ, Dong X, Cao YY, Yuan YD, Yang YB, Yan YQ, Akdis CA, Gao YD. Clinical characteristics of 140 patients infected with SARS-CoV-2 in Wuhan, China. Allergy. $\quad 2020$ Feb 19;75(7):1730-41. doi: 10.1111/all.14238.

82. Xu Y, Li X, Zhu B, Liang H, Fang C, Gong Y, Guo Q, Sun $\mathrm{X}$, Zhao D, Shen J, Zhang $\mathrm{H}$. Characteristics of pediatric SARS-CoV-2 infection and potential evidence for persistent fecal viral shedding. Nature Medicine. 2020 Mar 13;26:502-5. doi: 10.1038/s41591-020-0817-4. 
83. Chung M, Bernheim A, Mei X, Zhang N, Huang M, Zeng X, Cui J, Xu W, Yang Y, Fayad ZA, Jacobi A. CT imaging features of 2019 novel coronavirus (2019nCoV). Radiology. 2020 Apr;295(1):202-7. doi: 10.1148/radiol.2020200230.

84. Kanne JP. Chest CT findings in 2019 novel coronavirus (2019-nCoV) infections from Wuhan, China: key points for the radiologist. Radiology 2020;295(1):16-7. doi: 10.1148/radiol.2020200241.

85. Li X, Geng M, Peng Y, Meng L, Lu S. Molecular immune pathogenesis and diagnosis of COVID-19. Journal of Pharmaceutical Analysis. 2020 Mar 5;10(2):102-8. doi: 10.1016/j.jpha.2020.03.001.

86. Li Z, Yi Y, Luo X, Xiong N, Liu Y, Li S, Sun R, Wang Y, $\mathrm{Hu}$ B, Chen W, Zhang Y. Development and Clinical Application of A Rapid IgM-IgG Combined Antibody Test for SARS-CoV-2 Infection Diagnosis. Journal of medical virology. 2020 Feb 27;Early View. doi: 10.1002/jmv.25727.

87. Liu W, Liu L, Kou G, Zheng Y, Ding Y, Ni W, Wang Q, Tan L, Wu W, Tang S, Xiong Z. Evaluation of Nucleocapsid and Spike Protein-based ELISAs for detecting antibodies against SARS-CoV-2. Journal of Clinical Microbiology. 2020 Mar 30;58: e00461-20. doi: 10.1128/JCM.00461-20.

88. Li G, De Clercq E. Therapeutic options for the 2019 novel coronavirus (2019-nCoV). Nature Reviews Drug Discovery 2020;19:149-50. doi: 10.1038/d41573-02000016-0.

89. Liu W, Morse JS, Lalonde T, Xu S. Learning from the past: possible urgent prevention and treatment options for severe acute respiratory infections caused by 2019nCoV. Chembiochem. 2020 Mar 2. doi: 10.26434/chemrxiv.11728983.v1.

90. Du L, He Y, Zhou Y, Liu S, Zheng BJ, Jiang S. The spike protein of SARS-CoV-a target for vaccine and therapeutic development. Nature Reviews Microbiology. 2009 Mar;7(3):226-36. doi: 10.1038/nrmicro2090.

91. Grum-Tokars V, Ratia K, Begaye A, Baker SC, Mesecar AD. Evaluating the 3C-like protease activity of SARSCoronavirus: recommendations for standardized assays for drug discovery. Virus research. 2008 Apr 1;133(1):63-73. doi: 10.1016/j.virusres.2007.02.015.

92. Shum KT, Tanner JA. Differential inhibitory activities and stabilisation of DNA aptamers against the SARS coronavirus helicase. Chembiochem. 2008 Dec 15;9(18):3037-45. doi: 10.1002/cbic.200800491.

93. Xu X, Liu Y, Weiss S, Arnold E, Sarafianos SG, Ding J. Molecular model of SARS coronavirus polymerase: implications for biochemical functions and drug design. Nucleic acids research. 2003 Dec 15;31(24):7117-30. doi: 10.1093/nar/gkg916.
94. Zhang H, Penninger JM, Li Y, Zhong N, Slutsky AS. Angiotensin-converting enzyme 2 (ACE2) as a SARSCoV-2 receptor: molecular mechanisms and potential therapeutic target. Intensive Care Medicine. 2020 Mar 3;46:586-90. doi: 10.1007/s00134-020-05985-9.

95. Gurwitz D. Angiotensin receptor blockers as tentative SARS-CoV-2 therapeutics. Drug development research. 2020 Mar 4;81(5):537-40. doi: 10.1002/ddr.21656.

96. Yang Y, Islam MS, Wang J, Li Y, Chen X. Traditional Chinese Medicine in the Treatment of Patients Infected with 2019-New Coronavirus (SARS-CoV-2): A Review and Perspective. International Journal of Biological Sciences. 2020;16(10):1708-17. doi: 10.7150/ijbs.45538.

97. Wang $M$, Cao R, Zhang L, Yang X, Liu J, Xu M, Shi Z, $\mathrm{Hu} \mathrm{Z}$, Zhong W, Xiao G. Remdesivir and chloroquine effectively inhibit the recently emerged novel coronavirus (2019-nCoV) in vitro. Cell research. 2020 Mar;30(3):269-71. doi: 10.1038/s41422-020-0282-0.

98. Holshue ML, DeBolt C, Lindquist S, Lofy KH, Wiesman J, Bruce H, Spitters C, Ericson K, Wilkerson S, Tural A, Diaz G. First case of 2019 novel coronavirus in the United States. New England Journal of Medicine. 2020 Jan 31;382:929-936. doi: 10.1056/NEJMoa2001191.

99. Liu J, Cao R, Xu M, Wang X, Zhang H, Hu H, Li Y, Hu Z, Zhong W, Wang M. Hydroxychloroquine, a less toxic derivative of chloroquine, is effective in inhibiting SARS-CoV-2 infection in vitro. Cell discovery. $2020 \mathrm{Mar}$ 18;6(1):Article no 16. doi: 10.1038/s41421-020-0156-0.

100.Choy KT, Wong AY, Kaewpreedee P, Sia SF, Chen D, Hui KP, Chu DK, Chan MC, Cheung PP, Huang X, Peiris M. Remdesivir, lopinavir, emetine, and homoharringtonine inhibit SARS-CoV-2 replication in vitro. Antiviral Research. 2020 Apr 3;178:104786. doi: 10.1016/j.antiviral.2020.104786.

101.Caly L, Druce JD, Catton MG, Jans DA, Wagstaff KM. The FDA-approved Drug Ivermectin inhibits the replication of SARS-CoV-2 in vitro. Antiviral Research. $2020 \quad$ Apr 3;178:104787. doi: 10.1016/j.antiviral.2020.104787.

102.Sheahan TP, Sims AC, Zhou S, Graham RL, Pruijssers AJ, Agostini ML, Leist SR, Schäfer A, Dinnon KH, Stevens LJ, Chappell JD. An orally bioavailable broadspectrum antiviral inhibits SARS-CoV-2 in human airway epithelial cell cultures and multiple coronaviruses in mice. Science Translational Medicine. 2020 Apr 6;12(541): eabb5883. doi: 10.1126/scitranslmed.abb5883.

103.Hoffmann M, Kleine-Weber H, Schroeder S, Krüger N, Herrler T, Erichsen S, Schiergens TS, Herrler G, Wu NH, Nitsche A, Müller MA. SARS-CoV-2 cell entry depends on ACE2 and TMPRSS2 and is blocked by a clinically proven protease inhibitor. Cell. 2020 Mar 5;181(2):27180. doi: 10.1016/j.cell.2020.02.052. 
104.Ye X, Luo Y, Xia S, Sun Q, Ding J, Zhou Y, Chen W, et al. Clinical efficacy of lopinavir/ritonavir in the treatment of Coronavirus disease 2019. European Review for Medical and Pharmacological Sciences. 2020;24:3390-6. doi: 10.26355/eurrev_202003_20706.

105.Cao B, Wang Y, Wen D, Liu W, Wang J, Fan G, Ruan L, Song B, Cai Y, Wei M, Li X. A trial of lopinavir-ritonavir in adults hospitalized with severe Covid-19. New England Journal of Medicine. 2020 Mar 18;382:1787-99. doi: 10.1056/NEJMoa2001282.

106.Amanat F, Krammer F. SARS-CoV-2 Vaccines: Status Report. Immunity. 2020 Apr 6;52(4):583-9. doi: 10.1016/j.immuni.2020.03.007.

107.Kupferschmidt K, Cohen J. WHO launches global megatrial of the four most promising coronavirus treatments. Science. 2020 Mar 22. Available at: https://www.sciencemag.org/news/2020/03/wholaunches-global-megatrial-four-most-promisingcoronavirus-treatments (Accessed: 10 April 2020).

108.Wishart DS, Feunang YD, Guo AC, Lo EJ, Marcu A, Grant JR, Sajed T, Johnson D, Li C, Sayeeda Z, Assempour N, Iynkkaran I, Liu Y, Maciejewski A, Gale N, Wilson A, Chin L, Cummings R, Le D, Pon A, Knox C, Wilson M. DrugBank 5.0: a major update to the DrugBank database for 2018. Nucleic Acids Res. 2017 Nov 8;46(D1):1074-82. doi: 10.1093/nar/gkx1037.

109.Zhou Y, Hou Y, Shen J, Huang Y, Martin W, Cheng F. Network-based drug repurposing for novel coronavirus 2019-nCoV/SARS-CoV-2. Cell Discovery. 2020 Mar 16;6(1):Article no 14. doi: 10.1038/s41421-020-0153-3.

110.Chen CN, Lin CP, Huang KK, Chen WC, Hsieh HP, Liang $\mathrm{PH}$, Hsu JT. Inhibition of SARS-CoV 3C-like protease activity by theaflavin-3, 3'-digallate (TF3). Evidence-Based Complementary and Alternative Medicine. 2005;2(2):209-15. doi: 10.1093/ecam/neh081.

111.Jain RP, Pettersson HI, Zhang J, Aull KD, Fortin PD, Huitema C, Eltis LD, Parrish JC, James MN, Wishart DS, Vederas JC. Synthesis and evaluation of keto-glutamine analogues as potent inhibitors of severe acute respiratory syndrome 3CLpro. Journal of medicinal chemistry. 2004 Dec 2;47(25):6113-6. doi: 10.1021/jm0494873.

112.Ryu YB, Jeong HJ, Kim JH, Kim YM, Park JY, Kim D, Naguyen TT, Park SJ, Chang JS, Park KH, Rho MC. Biflavonoids from Torreya nucifera displaying SARS$\mathrm{CoV}$ 3CLpro inhibition. Bioorganic \& medicinal chemistry. 2010 Nov 15;18(22):7940-7. doi: 10.1016/j.bmc.2010.09.035.

113.Tanner JA, Zheng BJ, Zhou J, Watt RM, Jiang JQ, Wong KL, Lin YP, Lu LY, He ML, Kung HF, Kesel AJ. The adamantane-derived bananins are potent inhibitors of the helicase activities and replication of SARS coronavirus. Chemistry \& biology. 2005 Mar 1;12(3):303-11. doi: 10.1016/j.chembiol.2005.01.006.
114.Barnard DL, Hubbard VD, Burton J, Smee DF, Morrey JD, Otto MJ, Sidwell RW. Inhibition of severe acute respiratory syndrome-associated coronavirus (SARSCoV) by calpain inhibitors and $\beta$-D-N4hydroxycytidine. Antiviral Chemistry and Chemotherapy. $2004 \quad$ Feb;15(1):15-22. doi: 10.1177/095632020401500102.

115.Cho JK, Curtis-Long MJ, Lee KH, Kim DW, Ryu HW, Yuk HJ, Park KH. Geranylated flavonoids displaying SARS-CoV papain-like protease inhibition from the fruits of Paulownia tomentosa. Bioorganic \& medicinal chemistry. 2013 Jun 1;21(11):3051-7. doi: 10.1016/j.bmc.2013.03.027.

116.Berry JD, Hay K, Rini JM, Yu M, Wang L, Plummer FA, Corbett CR, Andonov A. Neutralizing epitopes of the SARS-CoV S-protein cluster independent of repertoire, antigen structure or $\mathrm{mAb}$ technology. InMAbs $2010 \mathrm{Jan}$ 1 (Vol. 2, No. 1, pp. 53-66). Taylor \& Francis. doi: 10.4161/mabs.2.1.10788.

117.Sui J, Li W, Murakami A, Tamin A, Matthews LJ, Wong SK, Moore MJ, Tallarico AS, Olurinde M, Choe H, Anderson LJ. Potent neutralization of severe acute respiratory syndrome (SARS) coronavirus by a human $\mathrm{mAb}$ to $\mathrm{S} 1$ protein that blocks receptor association. Proceedings of the National Academy of Sciences. 2004 Feb 24;101(8):2536-41. doi: 10.1073/pnas.0307140101.

118. Berry JD, Hay K, Rini JM, Yu M, Wang L, Plummer FA, Corbett CR, Andonov A. Neutralizing epitopes of the SARS-CoV S-protein cluster independent of repertoire, antigen structure or $\mathrm{mAb}$ technology. InMAbs $2010 \mathrm{Jan}$ 1 (Vol. 2, No. 1, pp. 53-66). Taylor \& Francis. doi: 10.4161/mabs.2.1.10788.

119.Tian X, Li C, Huang A, Xia S, Lu S, Shi Z, Lu L, Jiang S, Yang Z, Wu Y, Ying T. Potent binding of 2019 novel coronavirus spike protein by a SARS coronavirusspecific human monoclonal antibody. Emerging microbes \& infections. 2020 Jan 1;9(1):382-5. doi: 10.1080/22221751.2020.1729069.

120.Elshabrawy HA, Coughlin MM, Baker SC, Prabhakar BS. Human monoclonal antibodies against highly conserved HR1 and HR2 domains of the SARS-CoV spike protein are more broadly neutralizing. Plos one. 2012;7(11): e50366. doi: 10.1371/journal.pone.0050366.

121.Walls AC, Xiong X, Park YJ, Tortorici MA, Snijder J, Quispe J, Cameroni E, Gopal R, Dai M, Lanzavecchia A, Zambon M. Unexpected receptor functional mimicry elucidates activation of coronavirus fusion. Cell. 2019 Feb 21;176(5):1026-39. doi: 10.1016/j.cell.2018.12.028.

122.Kruse RL. Therapeutic strategies in an outbreak scenario to treat the novel coronavirus originating in Wuhan, China. F1000Research. 2020;9:72. doi: 10.12688/f1000research.22211.2. 
123.Cinatl J, Morgenstern B, Bauer G, Chandra P, Rabenau H, Doerr HW. Treatment of SARS with human interferons. The Lancet. 2003 Jul 26;362(9380):293-4. doi: 10.1016/S0140-6736(03)13973-6.

124.Hensley LE, Fritz EA, Jahrling PB, Karp C, Huggins JW, Geisbert TW. Interferon- $\beta$ 1a and SARS coronavirus replication. Emerging infectious diseases. 2004 Feb;10(2):317. doi: 10.3201/eid1002.030482.

125. Falzarano D, De Wit E, Martellaro C, Callison J, Munster VJ, Feldmann $H$. Inhibition of novel $\beta$ coronavirus replication by a combination of interferon- $\alpha 2 b$ and ribavirin. Scientific reports. 2013 Apr 18;3:1686. doi: $10.1038 /$ srep01686.

126.Kopecky-Bromberg SA, Martínez-Sobrido L, Frieman M, Baric RA, Palese P. Severe acute respiratory syndrome coronavirus open reading frame (ORF) $3 \mathrm{~b}$, ORF 6, and nucleocapsid proteins function as interferon antagonists. Journal of virology. 2007 Jan 15;81(2):54857. doi: 10.1128/JVI.01782-06.

127.Sallard E, Lescure FX, Yazdanpanah Y, Mentre F, Peiffer-Smadja N, Florence AD, et al. Type 1 interferons as a potential treatment against COVID-19. Antiviral Research. 2020 Apr 7;178:104791. doi: 10.1016/j.antiviral.2020.104791.

128.Lokugamage KG, Hage A, Schindewolf C, Rajsbaum R, Menachery VD. SARS-CoV-2 sensitive to type I interferon pretreatment. BioRxiv. 2020 Jan 1. doi: 10.1101/2020.03.07.982264.

129.Hannon GJ. RNA interference. nature. 2002 Jul;418(6894):244-51. doi: 10.1038/418244a.

130.Shi Y. Mammalian RNAi for the masses. TRENDS in Genetics. 2003 Jan 1;19(1):9-12. doi: 10.1016/S01689525(02)00005-7.

131.Haasnoot J, Cupac D, Berkhout B. Inhibition of virus replication by RNA interference. Journal of biomedical science. 2003 Oct 1;10(6):607-16. doi: 10.1007/BF02256311.

132.Qin ZL, Zhao P, Zhang XL, Yu JG, Cao MM, Zhao LJ, Luan J, Qi ZT. Silencing of SARS-CoV spike gene by small interfering RNA in HEK 293T cells. Biochemical and biophysical research communications. 2004 Nov 26;324(4):1186-93. doi: 10.1016/j.bbrc.2004.09.180.

133.Åkerström S, Mirazimi A, Tan YJ. Inhibition of SARS$\mathrm{CoV}$ replication cycle by small interference RNAs silencing specific SARS proteins, $7 \mathrm{a} / 7 \mathrm{~b}, 3 \mathrm{a} / 3 \mathrm{~b}$ and $\mathrm{S}$. Antiviral research. 2007 Mar 1;73(3):219-27. doi: 10.1016/j.antiviral.2006.10.008.

134.Wu CJ, Huang HW, Liu CY, Hong CF, Chan YL. Inhibition of SARS-CoV replication by siRNA. Antiviral research. 2005 Jan 1;65(1):45-8. doi: 10.1016/j.antiviral.2004.09.005.
135.Li BJ, Tang Q, Cheng D, Qin C, Xie FY, Wei Q, Xu J, Liu Y, Zheng BJ, Woodle MC, Zhong N. Using siRNA in prophylactic and therapeutic regimens against SARS coronavirus in Rhesus macaque. Nature medicine. 2005 Sep;11(9):944-51. doi: 10.1038/nm1280.

136.Sarkar B, Islam SS, Zohora US, Ullah MA. Virus like particles-A recent advancement in vaccine development. Korean Journal of Microbiology. 2019 Dec;55(4):327-43.

137.Siegrist CA. Vaccine immunology. Vaccines. 2008 Feb 11;5(1):17-36. doi: 10.1016/B978-1-4160-3611-1.500064.

138.Thanh Le T, Andreadakis Z, Kumar A, Gómez Román $\mathrm{R}$, Tollefsen S, Saville $\mathrm{M}$ et al. The COVID-19 vaccine development landscape. Nature Reviews Drug Discovery. 2020;19:305-6. doi: 10.1038/d41573-02000073-5.

139.Milkeninstitute.org.2020(Cited:14April2020). Available at: https://milkeninstitute.org/sites/default/files/202004/Covid19\%20Tracker\%20NEW4-9-20-2.pdf

140.China's CanSino Bio advances COVID-19 vaccine into phase 2 on preliminary safety data [Internet]. FiercePharma. 2020 (Cited: 14 April 2020). Available at: https://www.fiercepharma.com/vaccines/china-scansino-bio-advances-covid-19-vaccine-into-phase-2preliminary-safety-data

141.University of Oxford Commences Clinical Trial for Vaccine Candidate (ChAdOx1 nCoV-19) Targeting COVID-19. Trial Site News. 2020 (Cited: 14 April 2020). Available at: https://www.trialsitenews.com/universityof-oxford-commences-clinical-trial-for-vaccinecandidate-chadox1-ncov-19-targeting-covid-19-2

142. Woodcock J, Woosley R. The FDA critical path initiative and its influence on new drug development. Annu. Rev. Med.. 2008 Feb 18;59:1-2. doi: 10.1146/annurev.med.59. 090506.155819 .

143.CanSino Biological, Moderna, and INOVIO Lead COVID-19 Vaccine Race; 42 Other Candidates in PreClinicalStage. TrialSiteNews.2020(Cited:14April2020). Available from: https://www.trialsitenews.com/cansinobiological-moderna-and-inovio-lead-covid-19-vaccinerace-42-other-candidates-in-pre-clinical-stage

144.A Phase I Clinical Trial in 18-60 Adults - Full Text View - ClinicalTrials.gov [Internet]. Clinicaltrials.gov. 2020 (Cited: 14 April 2020). Available at: https:/clinicaltrials.gov/ct2/show/NCT04313127

145.A Phase II Clinical Trial to Evaluate the Recombinant Novel Coronavirus Vaccine (Adenovirus Vector) - Full Text View - ClinicalTrials.gov [Internet]. Clinicaltrials.gov.2020(Cited:14April2020).Availableat: https://www.clinicaltrials.gov/ct2/show/NCT04341389

146.Ad5-nCoV - DrugBank [Internet]. Drugbank.ca. 2020 (Cited: 14 April 2020). Available at: https://www.drugbank.ca/drugs/DB15655 
147.ChAdOx1 nCoV-19 - DrugBank. Drugbank.ca. 2020 (Cited: 14 April 2020). Available at: https://www.drugbank.ca/drugs/DB15656

148. A Study of a Candidate COVID-19 Vaccine (COV001) Full Text View - ClinicalTrials.gov. Clinicaltrials.gov. 2020 (Cited: 14 April 2020). Available at: https://clinicaltrials.gov/ct2/show/NCT04324606

149. NIH clinical trial of investigational vaccine for COVID19 begins. National Institutes of Health (NIH). 2020 (Cited: 14 April 2020). Available at: https://www.nih.gov/news-events/news-releases/nihclinical-trial-investigational-vaccine-covid-19-begins

150.Safety and Immunogenicity Study of 2019-nCoV Vaccine (mRNA-1273) for Prophylaxis SARS CoV-2 Infection (COVID-19) - Full Text View ClinicalTrials.gov. Clinicaltrials.gov. 2020 (Cited: 14 April 2020). Available at: https://clinicaltrials.gov/ct2/show/NCT04283461

151.Safety and Immunity of Covid-19 aAPC Vaccine - Full Text View - ClinicalTrials.gov. Clinicaltrials.gov. 2020 (Cited: 14 April 2020). Available at: https://clinicaltrials.gov/ct2/show/NCT04299724

152.Immunity and Safety of Covid-19 Synthetic Minigene Vaccine - Full Text View - ClinicalTrials.gov. Clinicaltrials.gov. 2020 (Cited: 14 April 2020). Available at: https://clinicaltrials.gov/ct2/show/NCT04276896

153.INOVIO Initiates Phase 1 Clinical Trial Of Its COVID19 Vaccine and Plans First Dose Today. Ir.inovio.com. 2020 (Cited: 14 April 2020). Available at: http://ir.inovio.com/news-and-media/news/pressrelease-details/2020/INOVIO-Initiates-Phase-1Clinical-Trial-Of-Its-COVID-19-Vaccine-and-PlansFirst-Dose-Today/default.aspx

154.Safety, Tolerability and Immunogenicity of INO-4800 for COVID-19 in Healthy Volunteers - Full Text View ClinicalTrials.gov. Clinicaltrials.gov. 2020 (Cited: 14 April 2020). Available at: https://clinicaltrials.gov/ct2/ show/NCT04336410

155.2020 M, vaccine C. Cobra Biologics and the Karolinska Institutet collaborate to develop COVID-19 vaccine Cobra Bio. Cobra Bio. 2020 (Cited: 14 April 2020). Available at: https://www.cobrabio.com/News/March2020/Cobra-Karolinska-Institutet-COVID-19-Vaccine

156.Martin U. The Biologics News and Reports Portal. pipelinereview. 2020 (Cited: 14 April 2020). Available at: https://pipelinereview.com/index.php/2020033174166/ Vaccines/Cobra-Biologics-and-the-KarolinskaInstitutet-collaborate-to-develop-COVID-19vaccine.html

157.Tirumalaraju D. Cobra Biologics, Karolinska Institutet partner on Covid-19 vaccine. Pharmaceuticaltechnology.com. 2020 (Cited: 14 April 2020). Available at: https://www.pharmaceutical-technology.com/news/ cobra-biologics-karolinska-covid-vaccine/
158.Martin U. The Biologics News and Reports Portal. pipelinereview. 2020 (Cited: 14 April 2020). Available at: https://pipelinereview.com/index.php/2020021773810/ Vaccines/Zydus-Cadila-launches-a-fast-trackedprogramme-to-develop-vaccine-for-the-novelcoronavirus-2019-nCoV-COVID-19.html

159.Zydus Cadila accelerates COVID-19 vaccine research | PharmaTutor. Pharmatutor.org. 2020 (Cited: 14 April 2020). Available at: https://www.pharmatutor.org/ pharma-news/2020/zydus-cadila-accelerates-covid-19vaccine-research

160.Altimmune Becomes The Second Maryland-Based Biotech Advance Potential Coronavirus/COVID-19 Vaccine - BioBuzz. BioBuzz. 2020 (Cited: 14 April 2020). Available at: https://biobuzz.io/altimmune-becomesthe-second-maryland-based-biotech-advancepotential-coronavirus-covid-19-vaccine/

161.Altimmune develops single-dose intranasal vaccine for COVID-19. NS Healthcare. 2020 (Cited: 14 April 2020). Available at: https://www.google.com/amp/s/www.nshealthcare.com/news/altimmune-covid-19vaccine/amp/

162.Altimmune Partners with University of Alabama to Develop Intranasal Coronavirus Vaccine. mobile.Hospimedica.com. 2020 (Cited: 14 April 2020). Available at: https://mobile.hospimedica.com/covid19/articles/294781428/altimmune-partners-withuniversity-of-alabama-to-develop-intranasalcoronavirus-vaccine.html

163.Altimmune Completes First Development Milestone Toward a Single-Dose Intranasal COVID-19 Vaccine. Truffle. 2020 (Cited: 14 April 2020). Available at: https://www.truffle.com/en/actualites/altimmunefranchit-une-premiere-etape-de-developpement-versun-vaccin-covid-19-intranasal-a-dose-unique

164.Post T. Pharma firm Anges and Osaka University to begin testing coronavirus vaccine on animals. The Jakarta Post. 2020 (Cited: 14 April 2020). Available at: https://www.google.com/amp/s/www.thejakartapost.co $\mathrm{m} / \mathrm{amp} /$ news/2020/03/24/pharma-firm-anges-andosaka-university-to-begin-testing-coronavirus-vaccineon-animals.html

165.Pharma Firm AnGes and Osaka University to Initiate Coronavirus Vaccine Testing on Animals. GeneOnline News. 2020 (Cited: 14 April 2020). Available at: https:/geneonline.news/en/2020/03/25/pharma-firmanges-and-osaka-university-to-initiate-coronavirusvaccine-testing-on-animals/?doing_wp_cron $=1586778$ 205.3787479400634765625000

166.Sanofi: Press Releases, Friday, March 27, 2020. (Cited: 14 April 2020). Available at: https://www.sanofi.com/en/ media-room/press-releases/2020/2020-03-27-07-00-00 
167.Tone S. Four Vaccine Types That Could Stop the Coronavirus, Explained. Sixth Tone. 2020 (Cited: 14 April 2020). Available at: https://www.sixthtone.com/ news/1005398/four-vaccine-types-that-could-stop-thecoronavirus\%2C-explained

168.CEPI collaborates with Institut Pasteur to develop COVID-19 vaccine. Biospectrumasia.com. 2020 (Cited: 14 April 2020). Available at: https://www.biospectrum asia.com/news/26/15637/cepi-collaborates-withinstitut-pasteur-to-develop-covid-19-vaccine.html

169. Researchers in Pittsburgh, Paris and Vienna Win Grant for COVID-19 Vaccine. Pittwire. 2020 (Cited: 14 April 2020). Available at: https://www.pittwire.pitt.edu/ news/researchers-pittsburgh-paris-and-vienna-wingrant-covid-19-vaccine

170.Russian Vaccine against COVID-19 Put on WHO List of Promising Vaccines. GMP news. 2020 (Cited: 14 April 2020). Available at: https://gmpnews.net/2020/04/ russian-vaccine-against-covid-19-put-on-who-list-ofpromising-vaccines/

171.Russian vaccine put on WHO list of promising anticoronavirus vaccines. TASS. 2020 (Cited: 14 April 2020). Available at: https://tass.com/science/1141257

172.Coronavirus: Russian vaccine put on WHO list. 2020 (Cited: 14 April 2020). Available at: https://www.banglanews24.com/english/health/article/ 83431/Coronavirus-Russian-vaccine-put-on-WHO-list
173.Mariano Esteban: "We need to use all clinical means to protect the population, slow down the infection, and allow the body to overcome it" - Grupo MAPFRE Corporativo - Acerca de MAPFRE. Grupo MAPFRE Corporativo - Acerca de MAPFRE. 2020 (Cited: 14 April 2020). Available at: https://www.mapfre.com/en/ interview-mariano-esteban/

174.Medeiros D. Press Release: Immunomic Therapeutics Forms Collaboration with EpiVax and PharmaJet to Develop Novel Vaccine Candidate Against COVID-19 Using its Investigational UNITE Platform - EpiVax, Inc. - Informatics and Immunology. EpiVax, Inc. Informatics and Immunology. 2020 (Cited: 14 April 2020). Available at: https://epivax.com/featured/pressrelease-immunomic-therapeutics-forms-collaborationwith-epivax-and-pharmajet-to-develop-novel-vaccinecandidate-against-covid-19-using-its-investigationalunite-platform

175.Tirumalaraju D, Tirumalaraju D. Immunomic partners EpiVax and PharmaJet on Covid-19 vaccine. Pharmaceutical-technology.com. 2020 (Cited: 14 April 2020). Available at: https://www.pharmaceuticaltechnology.com/news/immunomic-covid-19-vaccine/ 